\title{
A Mini-Review on Blue Light-Emitting Diodes Based on Metal-Halide Perovskite Nanocrystals
}

\author{
Sung-Doo Baek ${ }^{1 \dagger}$ \\ Seodaemun-gu, Seoul 03722, Republic of Korea

\section{금속-할로겐화물 페로브스카이트 나노결정 기반 청색 발광 다이오드의 연구동향}

${ }^{1}$ Yonsei University KIURI Institute, Department of Materials Science and Engineering, Yonsei University, 50 Yonsei-ro,

\author{
백성두 $^{1 \dagger}$ \\ ${ }^{1}$ 연세대학교 신소재공학과 KIURI연구단
}

(Received May 20 2021; Accepted May 26 2021)

\begin{abstract}
s
Metal-halide perovskite nanocrystals have attracted great scientific attention in the field of light-emitting diode (LED) due to their excellent optical and electrical properties such as narrow emission linewidth, photoluminescence quantum yield approaching unity, high charge carrier mobility, and halogen anion composition-dependent tunable bandgap. Over the last few years, considerable progress has been achieved on red and green perovskite LEDs (external quantum efficiencies exceeding $20 \%$ ), however, the performance of blue LEDs still lags far behind that of red and green counterparts. In this review, overall background of perovskite nanocrystal and research progress of perovskite nanocrystal-based blue LEDs are summarized.
\end{abstract}

Keywords: Metal-halide perovskite, Blue light-emitting diode, Nanocrystal

\section{1. 서론}

$\mathrm{ABX}_{3}\left[\mathrm{~A}=1\right.$ 가 유기 양이온: $\mathrm{CH}_{3} \mathrm{NH}_{3}^{+}$(methyl ammonium, $\left.\mathrm{MA}^{+}\right), \mathrm{CH}\left(\mathrm{NH}_{2}\right)_{2}{ }^{+}$(formamidinium,
$\mathrm{FA}^{+}$, 또는 무기 양이온: $\mathrm{Cs}^{+} ; \mathrm{B}=2$ 가 금속 양이온: $\mathrm{Pb}^{2+}, \mathrm{Sn}^{2+} ; \mathrm{X}=$ 할로겐 음이온: $\left.\mathrm{Cl}^{-}, \mathrm{Br}^{-}, \mathrm{I}^{-}\right]$의 구조 를 지니는 금속-할로겐화물 페로브스카이트는 좁은 방 출 선폭, 높은 흡광도 계수와 전하 운반자 이동도, 할로

†Corresponding Author: joshuabaek@yonsei.ac.k 
(a)

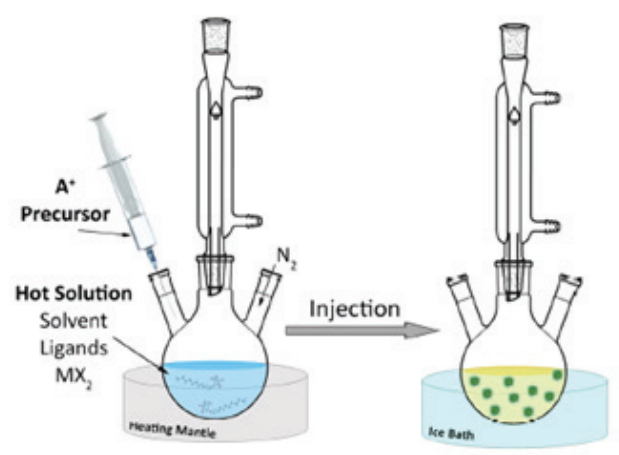

(b)

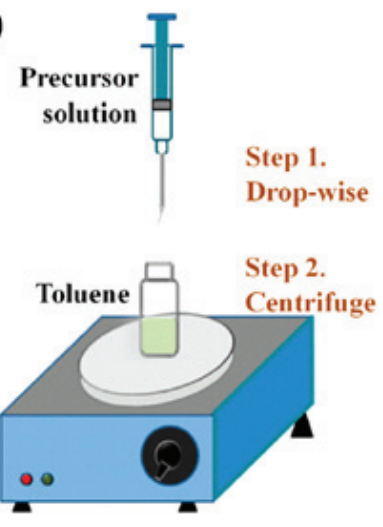

Fig. 1. (a) Hot injection 방법 모식도 Reproduced from Shamsi et al. Chem. Rev. 2019;119:3296-3348, with permission of American Chemical Society [19]. (b) LARP 방법 모식도. Reproduced from Zhang et al. ACS Nano 2015;9:4533-4542, with permission of American Chemical Society [17].

겐 음이온 조성에 따라 조절 가능한 밴드갭과 같은 우 수한 전기 · 광학적 특성으로 인해 차세대 광전자 재료 로 다양한 분야에서 많은 주목을 받고 있다..$^{1-5)}$ 특히, 페 로브스카이트 재료가 지니는 우수한 광 흡수율 특성으 로 인해 고체 태양 전지 분야에서 많은 연구가 이루어졌 으며, 이를 통해 현재 상용화되어 있는 실리콘 태양 전 지 광전 효율 수준에 준하는 성과를 이룩하였다. ${ }^{6)}$ 이러 한 페로브스카이트 재료가 지니는 우수한 전기 · 광학 적 특성은 발광 다이오드(light-emitting diode, LED) 분야에서도 많은 관심을 불러 일으켰으며, 2014년 Tan et al. 연구진에 의해 최초의 금속-할로겐화물 페로브 스카이트를 이용한 근적외선, 적색 및 녹색 $\mathrm{LED}$ 가 보고 되었다(외부 양자 효율: 각각 $0.76 \%, 0.1 \%, 0.018 \%$ ). 이후 금속-할로겐화물 페로브스카이트 기반 LED에 대 한 연구들이 활발하게 이루어지게 되었으며, 최근까지 의 다양한 연구들을 통해 근적외선, 적색 및 녹색 LED 는 외부 양자 효율이 $20 \%$ 를 상회하여 이론적 전환 효 율 수치인 25\%에 근접하는 수준까지 이르게 되었다. 8-11) $^{-1}$ 하지만, 청색 $\mathrm{LED}$ 는 상대적으로 낮은 발광 효율로 인 해 소자의 외부 양자 효율이 아직까지 타 색 대비 절반 에도 못 미치는 수준에 머무르고 있으므로, 이를 극복하 기 위한 더 많은 연구가 필요하다. 페로브스카이트 청색 $\mathrm{LED}$ 는 결정의 크기와 종류에 따른 3 차원의 벌크형 결 정, 준 2 차원(quasi-2D) 결정, 혹은 콜로이드성 나노결 정(nanocrystal)을 이용하여 구현 가능하다. ${ }^{12)}$ 본 총설 에서는 작은 결정 크기로 인해 상대적으로 높은 엑시톤 (exciton) 결합 에너지를 지녀 우수한 청색 LED 소재로 각광 받고 있는 금속-할로겐화물 페로브스카이트 나노 결정과, 이를 이용하여 제작한 청색 $\mathrm{LED}$ 의 연구동향에 대하여 기술하고자 한다.

\section{2. 폐로브스카이트 나노결정 합성}

\subsection{Hot-injection method}

Hot injection 방법은 합성에 필요한 한 전구체를 나 머지 전구체와 리간드가 용해되어 있는 뜨거운 용매에 순간적으로 주입하여 나노결정을 합성하는 방법이다 (Fig. 1a). 이 방법은 카드뮴 칼코겐화물 나노결정을 합 성하기 위해 처음 고안되었으며, 오늘날까지 다양한 콜 로이드성 나노결정들을 합성하기 위해 통상적으로 많 이 사용되는 방법이다. ${ }^{13)}$ 페로브스카이트 나노결정에서 는 2015년에 Protesescu et al. 연구진에 의해 처음으 로 hot-injection 방법에 의한 무기 페로브스카이트 나 노결정 $\left(\mathrm{CsPbX}_{3}, \mathrm{X}=\mathrm{Cl}, \mathrm{Br}, \mathrm{I}, \mathrm{Cl} / \mathrm{Br}\right.$, 또는 $\left.\mathrm{Br} / \mathrm{I}\right)$ 합성 법이 보고되었다. ${ }^{14)}$ 합성한 나노결정은 입방(cubic) 결 정 구조로 4-15 nm 크기를 지니며, 양자구속효과와 페 로브스카이트의 X 자리에 치환해주는 할로겐화물의 종 
류에 따라 밴드갭(bandgap)을 410-700 nm의 넓은 가 시광 영역 범위에서 조절 가능하였다. 나노결정의 광발 광(photoluminescence, PL) 반치전폭(full width at half maximum, FWHM)은 12-42 nm, PL 양자 수 율(photoluminescence quantum yield, PLQY) 50$90 \%$, 발광 수명(radiative lifetime)은 1-29 ns로 기 록되었다. 이후, 비슷한 방법으로 $\mathrm{A}$ 자리에 무기 이 온인 $\mathrm{Cs}^{+}$대신 $\mathrm{MA}^{+}$나 $\mathrm{FA}^{+}$를 사용한 $\mathrm{CH}_{3} \mathrm{NH}_{3} \mathrm{PbX}_{3}$ 와 $\mathrm{FAPbX}_{3}$ 유기 페로브스카이트 나노결정 합성법들도 보 고되었다. ${ }^{15), 16)}$ Hot injection 방법에 대하여 간략히 서 술해보면, 할로겐화물 납(lead halides) 전구체를 oleic acid 및 oleylamine과 같은 유기 리간드들과 함께 특정 온도의 불활성 기체 분위기에서 1-octadecene과 같은 유기 용매에 용해시킨다. 이후, 준비된 Cs-oleate 전구 체(무기 페로브스카이트의 경우)를 순간적으로 주입하 고 수 초간 반응 후, 반응계를 저온의 빙점조로 옮겨 반 응을 종결시키게 된다. 일반적으로, 반응에 사용되는 전 구체 및 리간드의 종류와 비율, 전구체의 주입 온도, 반 응 시간 등을 조절함으로써 나노결정의 크기 및 크기 분 포, 모양을 결정할 수 있다. ${ }^{1)}$

\subsection{Ligand-assisted reprecipitation (LARP) method}

LARP 방법은 콜로이드성 페로브스카이트 나노결정 을 합성할 때 사용되는 대표적인 또 다른 방법으로, 용 해도의 차이를 이용해 이온의 재결정을 유도하는 침전 법의 일종이다 (Fig. 1b). ${ }^{17)}$ 이온이 용매에 용해되어 평 형농도에 도달한 용액을 온도 변화(용액 냉각) 또는 용 매의 증발, 혼화성 공용매의 첨가를 통해 비평형 과포 화상태로 만들게 되면, 반응계가 다시 평형 상태에 도 달할 때까지 자발적인 침전 및 결정화 반응이 발생하 게 된다. LARP 방법은 이러한 재결정 과정에 리간드 를 첨가하여 페로브스카이트 결정 성장을 유한한 크기 로 억제시켜 나노결정의 형성을 유도하게 된다. 예를 들 어, $\mathrm{CsPbX}_{3}(\mathrm{X}=\mathrm{Cl}, \mathrm{Br}$, 또는 I)를 합성하는 경우, 페 로브스카이트 전구체 염 $\left(\mathrm{CsX}, \mathrm{PbX}_{2}\right)$ 을 oleylamine과 oleic acid 리간드와 함께 dimethylformanide (DMF) 나 dimethylsulfoxide (DMSO)와 같은 극성 용매에 용
해시키고, toluene이나 hexane과 같은 poor solvent에 천천히 적가(dropwise)하게 되면, 용매의 과포화에 의 해 $\mathrm{CsPbX}_{3}$ 나노결정의 핵생성과 성장이 일어나게 된다. LARP 방법은 2012년 Papavassiliou 연구진에 의해 처 음으로 유-무기 페로브스카이트 나노결정 합성에 응용 되었다. ${ }^{18)} \mathrm{MAPbX}_{3},(\mathrm{MA})\left(\mathrm{CH}_{3} \mathrm{C}_{6} \mathrm{H}_{4} \mathrm{CH}_{2} \mathrm{NH}_{3}\right)_{2} \mathrm{~Pb}_{2} \mathrm{X}_{7}$, $(\mathrm{MA})\left(\mathrm{C}_{4} \mathrm{H}_{9} \mathrm{NH}_{3}\right)_{2} \mathrm{~Pb}_{2} \mathrm{X}_{7}(\mathrm{X}=\mathrm{Br}, \mathrm{Cl}$, 또는 I)염을 $\mathrm{DMF}$ (또는 acetonitile)에 용해시키고, 이를 toluene(또는 toluene-PMMA mixture)에 적가하여 나노결정을 합 성하였다. 이러한 방식으로 얻어진 나노결정은 30-160 $\mathrm{nm}$ 의 크기를 지녔으며, 동일한 조성의 벌크 $\mathrm{MAPbX}_{3}$ 결정보다 더 강한 $\mathrm{PL}$ 세기를 나타내는 것이 관측되었 다. 이후, 여러 연구들을 통하여 다양한 페로브스카이 트 나노결정 합성을 위해 LARP법이 응용 - 발전되게 되 었다. ${ }^{19)}$ 이러한 LARP 방법은 전술한 hot-injection 방 법과 달리, 대기 분위기에서 복잡한 실험 장비 없이 간 단하게 수행 가능하며, 합성 시간도 매우 짧아 저비용의 용액형 제조 공정을 가능하게 하는 이점이 있다.

\section{3. 유기 리간드 제어}

콜로이드성 페로브스카이트 나노결정을 합성하는데 있어서 합성법만큼 중요한 것이 나노결정 표면에 결합

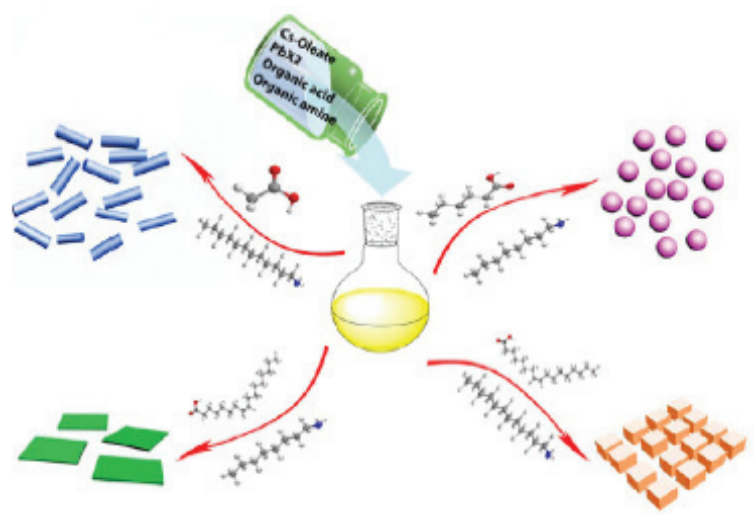

Fig. 2. 실온에서 유기산 및 아민 리간드에 의해 조절되는 다양한 형태의 $\mathrm{CsPbX}_{3}(X=\mathrm{Cl}, \mathrm{Br}$, 또는 I) 나노결정 형성 과정 모 식도 (구형 양자점: hexanoic acid, 나노큐브: oleic acid 및 dodecylamine, 나노로드: acetate acid 및 dodecylamine, 나노플레이트: oleic acid 및 octylamine). Reproduced from Sun et al. ACS Nano 2016;10:3648-3657, with permission of American Chemical Society [20]. 


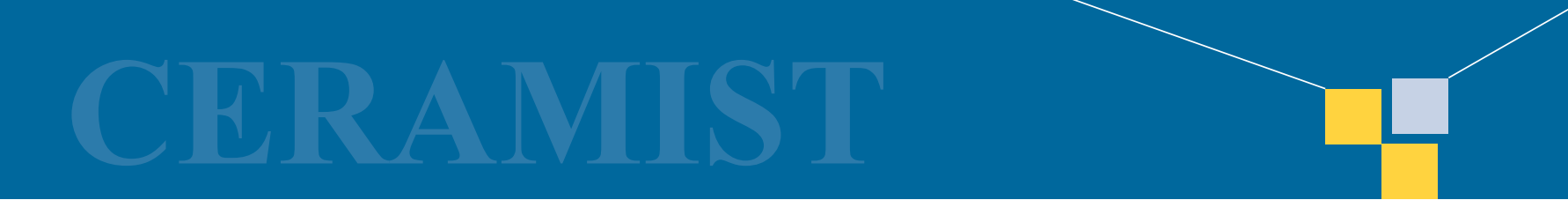

특 집 미백성두

되어 있는 유기리간드를 제어하는 것이다. 나노결정의 모양, 크기, 표면 및 광학적 특성, 안정성 등이 나노결 정 표면의 유기리간드에 의해 많이 결정되므로 이를 제 어하는 것이 필수적이다 (Fig. 2). 예를 들어, Sun et al. 연구진은 oleic acid와 oleylamine을 사용하여 입 방 형태의 페로브스카이트 나노결정을 합성할 수 있 을 뿐 아니라, oleylamine의 농도를 증가시킨 과량의 oleylamine 조건에서 나노로드 및 나노와이어 형태의 페로브스카이트 나노결정을 합성할 수 있음을 보고하 였다. ${ }^{20)}$ Yassitepe et al. 연구진은 나노결정의 안정성 을 향상시키기 위해 amine 없이 oleic acid만을 사용
하여 나노결정을 합성하고, 이를 LED에 응용하는 결 과를 보고하였다. ${ }^{21)}$ 또한, 입체 장해(steric hindrance) 를 유발하는 polyhedral oligomeric silsesquioxane (POSS), (3-aminopropyl)triethoxysilane (TPTES), tri-octylphosphine oxide (TOPO)와 같은 bulky 리간 드를 사용했을 때에도 나노결정의 분해 과정을 지연시 켜 안정성을 향상시키는 것이 확인되었으며, 이러한 리 간드들을 사용하는 경우, 페로브스카이트 나노결정의 표면결함들을 패시베이션(passivation)하여 PL 양자 효 율(photoluminescence quantum efficiency, PLQE) 이 크게 향상될 수 있음이 보고되었다. ${ }^{22-25)}$ 하지만 페로 (a)

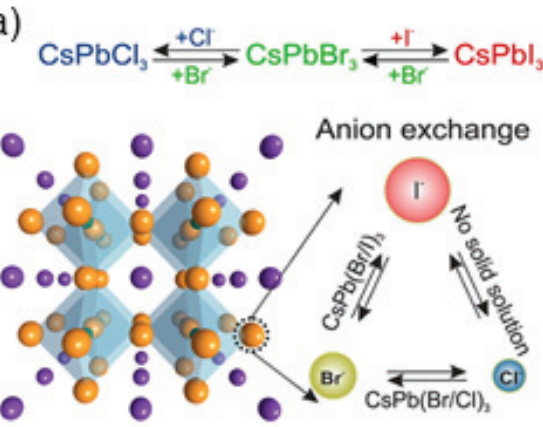

Precursors:

$\mathrm{Cl}: \mathrm{PbCl}_{2}, \mathrm{OAmCl}, \mathrm{MeMgCl}$

$\mathrm{Br}$ : $\mathrm{PbBr}_{2}, \mathrm{OAmBr}, \mathrm{MeMgBr}$

I: $\mathrm{Pbl}_{2}, \mathrm{OAml}, \mathrm{MeMgl}$ (b)

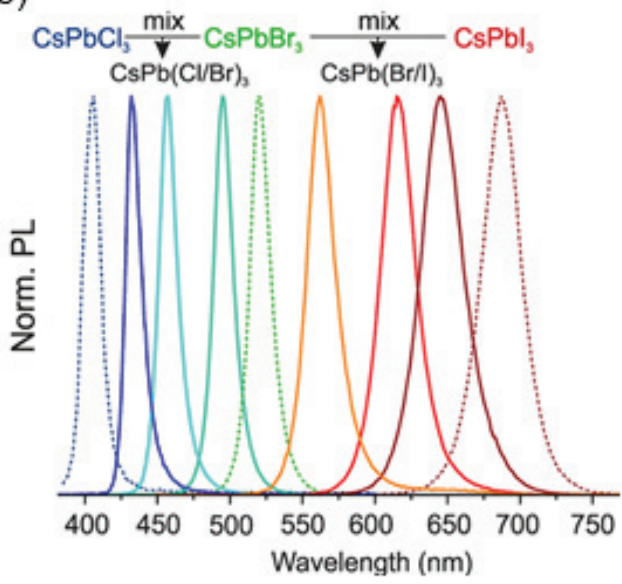

$+\mathrm{Cl}^{-}$
$\mathrm{CsPbBr}_{3}(10 \mathrm{~nm})$

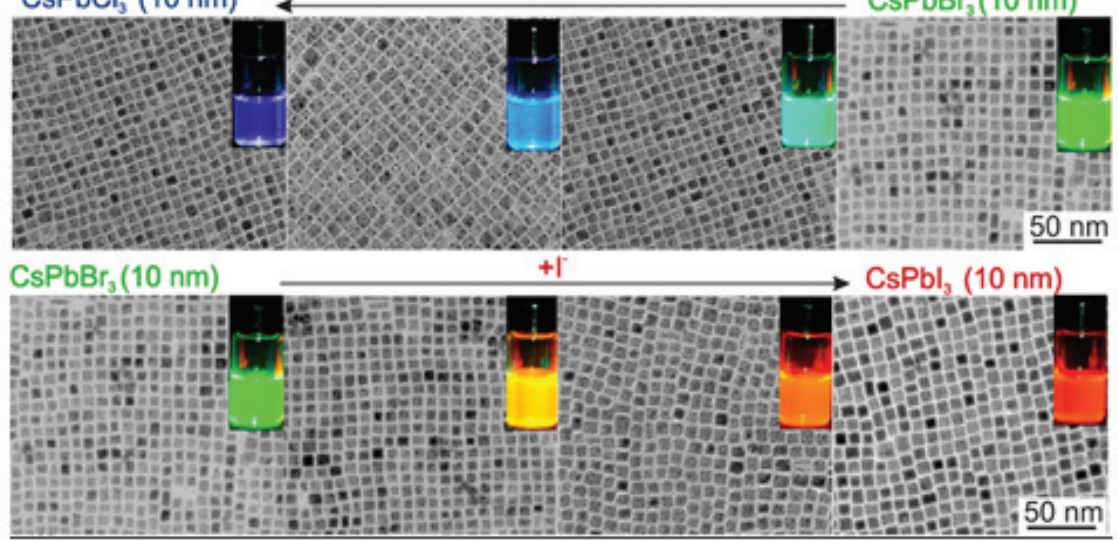

Fig. 3. (a) 입방형 $\mathrm{CsPbX}_{3}$ 페로브스카이트 결정 구조의 음이온 교환 모식도 및 각 반응에 적합한 시약 목록. (b) $\mathrm{CsPbCl}_{3}, \mathrm{CsPbBr}_{3}$ 및 $\mathrm{CsPb}_{3}$ 나노결정을 다양한 비율로 혼합하여 얻은 샘플의 $\mathrm{PL}$ 스펙트럼. (c) 음이온 교환법을 이용하여 수득한 $\mathrm{CsPb}_{3}$ 결정의 투 과 전자 현미경 이미지 및 PL 광학 이미지. Reproduced from Nedelcu et al. Nano Lett. 2015;15:5635-5640, with permission of American Chemical Society [27]. 
브스카이트 나노결정의 표면에 형성되어 있는 유기리간 드, 특히 긴 알킬 사슬을 가진 리간드는 낮은 전기 전도 도로 인해 LED에서 전하 운반자(charge carrier) 주입 장벽을 만들어 발광 소자의 성능 저하를 유발하므로 나 노결정의 안정성과 전기적 특성 간의 적절한 균형을 맞 추어 줄 수 있는 짧은 알킬 사슬을 가진 리간드를 선정 하여 최적화하는 것이 필요하다. ${ }^{26)}$

\section{3. 폐로브스카이트 나노결정의 조성 제어}

\section{1. $X$ 자리 조성 제어}

금속-할로겐화물 페로브스카이트 나노결정을 이용 하여 청색광을 구현하는 직관적이며 가장 단순한 방법 은 $\mathrm{ABX}_{3}$ 구조를 지니는 페로브스카이트의 $\mathrm{X}$ 자리 할로 겐 이온에 $\mathrm{Br}^{-}$과 $\mathrm{Cl}^{-}$를 함께 사용하는 혼합 조성의 페 로브스카이트 나노결정을 합성하는 것이다. 서론부에서 언급되었듯이, 금속-할로겐화물 페로브스카이트 재료 는 X 자리의 할로겐 이온 종류에 따라 밴드갭 조절이 가 능하므로, $\mathrm{Br}^{-}$과 $\mathrm{Cl}^{-}$의 적절한 조성비 제어를 통해 손쉽 게 청색광 구현이 가능하다. 할로겐 이온의 조성 제어는 크게 두 가지 방법으로 접근할 수 있는데 합성 과정에서 넣어주는 전구체의 조성비를 제어하는 방법과 합성이 끝난 후, 음이온 교환법(anion exchange method)을 이용하는 후처리 방식이 있다. 이온성 화합물인 페로브 스카이트는 단일 이온 전하, 양이온성 부격자(cationic sublattice)의 강성 및 효과적인 공공(vacancy) 기반 확 산 메커니즘으로 인해 할로겐 음이온이 쉽게 추출되고 다른 할로겐 음이온으로 대체가 가능하다. ${ }^{27)}$ 음이온 교 환법은 할로겐화물 혼합 조성의 페로브스카이트 나노 결정을 쉽게 얻어낼 수 있는 상대적으로 단순한 접근법 으로, 본 방법을 통해 청색광을 나타내는 혼합 할로겐 화물 조성의 $\mathrm{CsPb}(\mathrm{Br} / \mathrm{Cl})_{3}$ 나노결정을 성공적으로 수 득할 수 있음이 보고되었다. ${ }^{14)}$ 빠른 할로겐 음이온 교환 이 가능한 할로겐 화합물로는 유기금속 Grignard 시약 $(\mathrm{MeMgX})$, oleylammonium 할로겐화물 $(\mathrm{OAmX})$, 또 는 $\mathrm{PbX}_{2}$ 염 등이 있으며, 할로겐 음이온 교환 반응을 통
해 나노결정의 크기나 형태는 변화 없이 유지되는 것이 관측되었다 (Fig. 3).

\section{2. $\mathrm{B}$ 자리 도핑/치환}

페로브스카이트 결정의 상전이(phase transition) 에 의한 스펙트럼 불안정성과 비방사성 재결합 (nonradiative recombination)으로 인한 PL 효율 저하 는 고품위의 청색 페로브스카이트 나노결정 소재 개발 에 있어 큰 걸림돌이 되는 요소들이다. ${ }^{27,28)}$ 페로브스카 이트 재료는 결함 내성(defect tolerance)을 지니는 물 질이지만, 여전히 양이온 혹은 음이온 공공과 같은 전 형적인 결함이 존재하므로 도핑을 통해 결함 준위 밀도 를 감소시키고, 결정립계(grain boundary)를 패시베이 션하면 높은 PLQY와 안정성 및 우수한 전기적 특성을 확보할 수 있다. ${ }^{29)}$ 현재까지 다양한 금속 이온들 $\left(\mathrm{Al}^{3+}\right.$, $\mathrm{Bi}^{3+}, \mathrm{Ni}^{2+}, \mathrm{Cu}^{2+}, \mathrm{Zn}^{2+}, \mathrm{Cd}^{2+}, \mathrm{Nd}^{3+}$ 등)과 희토류 이온 들 $\left(\mathrm{Ce}^{3+}, \mathrm{Er}^{3+}, \mathrm{Tb}^{3+}\right.$ 등)을 페로브스카이트에 도핑한 결 과들이 보고되었다. ${ }^{30)}$

Zou et al. 연구진의 경우, 나노결정의 열적 안정성 과 광학적 특성을 향상시키기 위해 $\mathrm{Mn}^{2+}$ 치환을 실시 하였다. ${ }^{31)} \mathrm{Mn}^{2+}$ 치환은 나노결정의 형성 에너지를 증가 시켰으며, 이를 통해 페로브스카이트 격자의 안정성이 크게 향상되어 대기분위기 아래 $200{ }^{\circ} \mathrm{C}$ 의 고온에서도 나노결정이 안정적으로 존재하는 것이 확인되었다. 또 한, 이와 유사한 효과가 $\mathrm{Cu}^{2+}$ 를 나노결정에 도핑했을 때 에도 나타나는 것이 Bi et al. 연구진에 의해 보고되었 다. ${ }^{32)} \mathrm{Cu}^{2+}$ 가 $\mathrm{CsPbX}_{3}$ 의 $\mathrm{Pb}^{2+}$ 자리에 도핑되었을 때, 나 노결정의 열적 안정성이 크게 증가하여 $250{ }^{\circ} \mathrm{C}$ 에서도 안정적인 광 방출을 보이는 것이 관측되었다. 이는 상 대적으로 작은 크기의 $\mathrm{Cu}^{2+}$ 가 격자의 수축을 유발하고, 할로겐화물 공공(halides vacancy)을 제거하여 격자의 형성 에너지 증가와 단주기 규칙(short-range order) 을 향상시켰기 때문이다. 이렇게 도핑을 통하여 합성한 $\mathrm{CsPb}_{1-\mathrm{x}} \mathrm{Cu}_{\mathrm{x}}(\mathrm{Br} / \mathrm{Cl})_{3}$ 나노결정은 $450-460 \mathrm{~nm}$ 영역에 서의 밝은 청색 발광과 함께 $80 \%$ 가 넘는 높은 PLQY를 보이는 것이 확인되었다. 일반적으로 보고되는 $\mathrm{CsPbCl}_{3}$ 


\section{특 집 바맥성두}

(a)

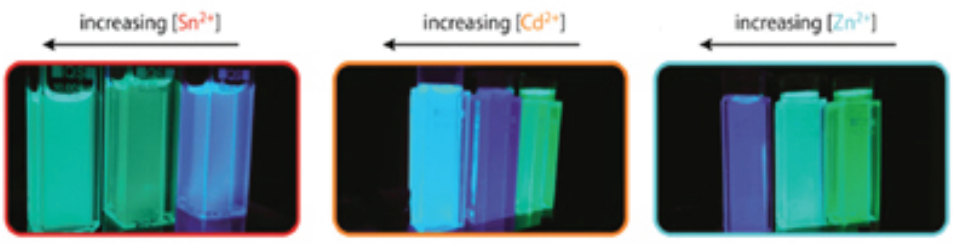

(b)

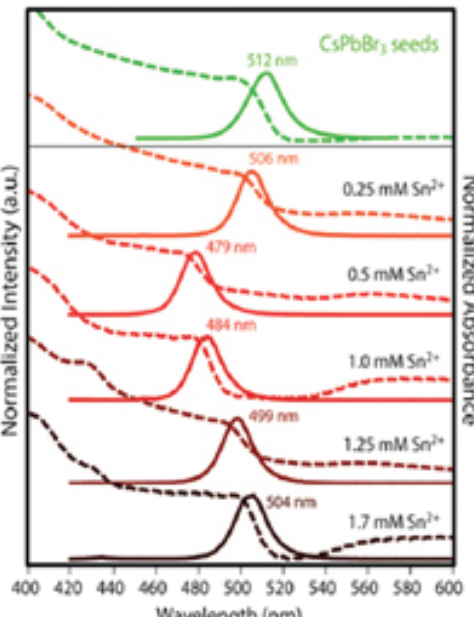

(c)
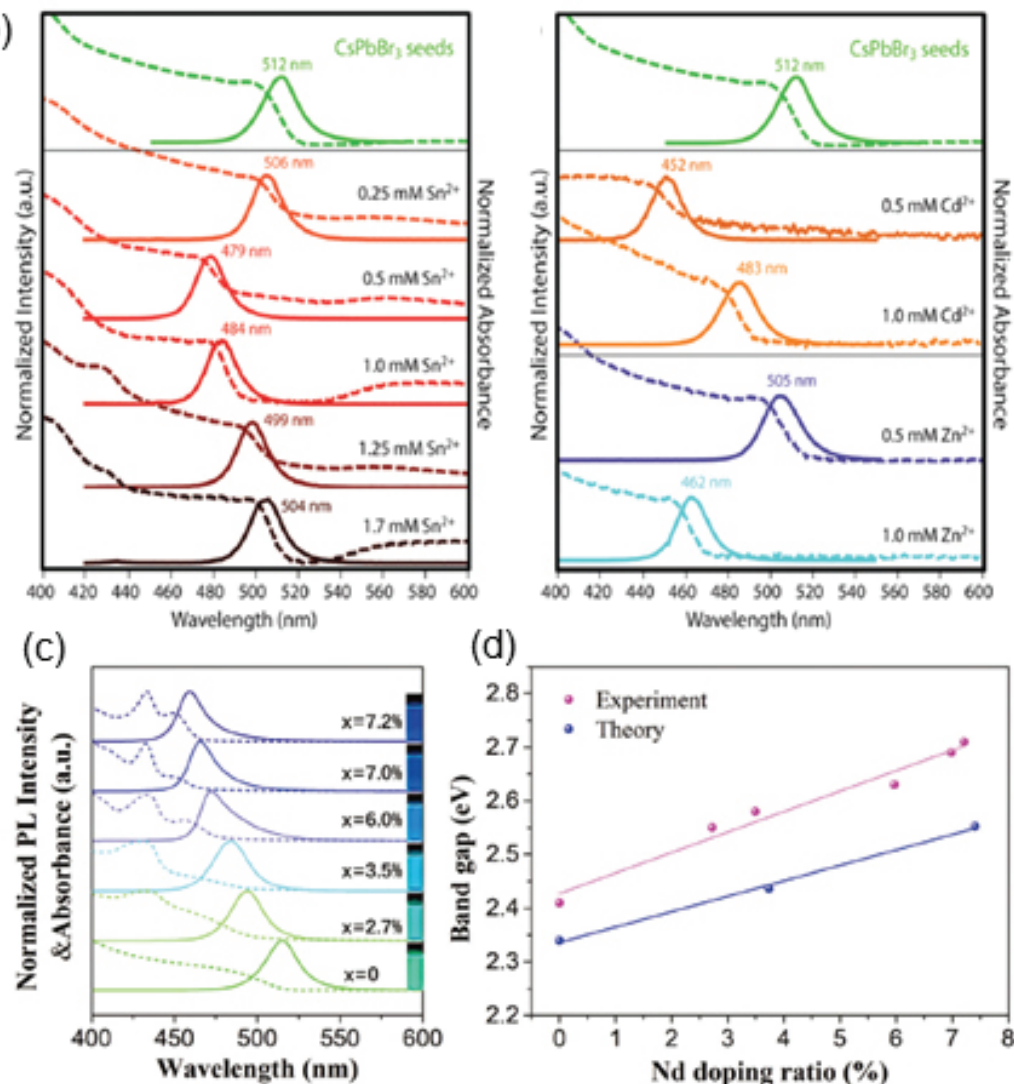

(d)

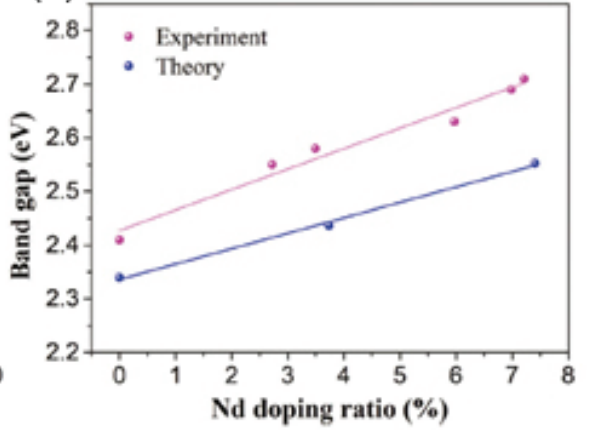

Fig. 4. 다른 종류의 이온 도핑 $\left(\mathrm{Sn}^{2+}, \mathrm{Cd}^{2+}, \mathrm{Zn}^{2+}\right)$ 에 따른 $\mathrm{CsPbBr}$ 나노결정의 (a) PL 광학 이미지. (b) PL(실선) 및 흡광(점선) 스펙트럼. $\mathrm{Re}-$ produced from Stam et al. J. Am. Chem. Soc. 2017;139:4087-4097, with permission of American Chemical Society [39]. Nd ${ }^{3+}$ 도핑 농도에 따른 $\mathrm{CsPbBr}_{3}$ 나노결정의 (c) PL 광학 이미지, PL 및 흡광 스펙트럼, (d) 실험 및 이론적 밴드갭 변화 추이. Reproduced from Xie et al. Adv. Sci. 2020;7:2001698, with permission of Wiley-VCH GmbH [40].

나노결정은 매우 저조한 PLQY 수치를 보여주는데 이 는 다양한 유형의 구조 및 표면 결함으로 인한 것일 수 있다. ${ }^{33), 34)}$ 전술하였듯이, 비록 납 할로겐화물 페로브스 카이트가 기존 II-VI 또는 III-V족 나노결정들 보다 높 은 결함 내성을 지니고 있을지라도, 양이온 또는 음이온 공공과 같은 전형적인 결함의 존재는 전도대 및 가전자 대 사이에 불필요한 에너지 준위를 형성하여 전하 운반 자의 trap으로 인한 상당한 방사성 재결합(radiavtive recombination)의 손실을 야기한다. Yong et al. 연구
진은 $\mathrm{CsPbCl}_{3}$ 나노결정에 $\mathrm{Ni}^{2+}$ 도핑을 통해 이러한 결 함들을 효과적으로 억제함으로써 격자의 단주기 규칙 향상에 의한 near-unity PLQY를 구현하였다. ${ }^{35)}$ 비슷 한 방식으로 3 가 금속 할로겐화물 역시 비방사성 재결 합을 유발하는 결함들을 억제하여 PLQY 향상이 가능 하다. Ahmed et al. 연구진은 $\mathrm{YCl}_{3}$ 의 $\mathrm{Y}^{3+}$ 와 $\mathrm{Cl}^{-}$를 이용 하여 $\mathrm{CsPbCl}_{3}$ 나노결정의 표면에 존재하는 $\mathrm{Pb}-\mathrm{Cl}$ 이온 쌍 결함(ion pair defect)을 채우고, 비 배위 $\mathrm{Pb}$ 원자를 효과적으로 패시베이션하는 결과를 보고하였다. ${ }^{36)} \mathrm{YCl}_{3}$ 
후처리를 이용한 $\mathrm{Y}^{3+}$ 의 격자 내 도핑을 통해 나노결정의 $\mathrm{PLQY}$ 가 후처리를 하지 않은 나노결정보다 약 60 배 정 도 더 향상되는 결과가 관측되었다.

페로브스카이트 나노결정의 효과적인 도핑/치환은 재 료의 특성 향상뿐만 아니라, 어느 정도 수준의 방출 파 장 변조를 유도하는 것도 가능하므로 X 자리에 순수한 $\mathrm{Br}^{-}$만을 이용하여 청색광을 구현하는 것도 가능하다. 특히, 이러한 도핑/치환은 페로브스카이트의 $\mathrm{A}$ 자리보 다는 $\mathrm{Pb}^{2+}$ 가 위치한 $\mathrm{B}$ 자리에 적용하는 것이 더 효과적 인데, 페로브스카이트의 전도대(conduction band)가 $\mathrm{Pb}^{2+}$ 의 $\mathrm{p}$ 오피탈 중첩에 의해 형성되기 때문이다. 예를 들어, $\mathrm{CsPbBr}_{3}$ 나노결정의 $\mathrm{Cs}^{+}$를 $\mathrm{CH}_{3} \mathrm{NH}_{3}{ }^{+}$로 치환하는 경우, 약간의 $\mathrm{PL}$ 피크 적색 편이(red shift)가 관측되는 반면, $\mathrm{Al}^{3+}$ 를 $\mathrm{Pb}^{2+}$ 자리에 도핑하면 나노결정 방출 파장 의 청색 편이 관측이 가능하다. ${ }^{37), 38)}$ 이런 경우, 나노 결 정의 PL 방출 파장이 기존 $515 \mathrm{~nm}$ 의 녹색에서 $456 \mathrm{~nm}$ 의 진청색까지 청색 편이(blue shift)되는 것이 보고되었 는데, 이는 $\mathrm{Al}$ 도핑이 $\mathrm{Al}$ 의 s 오비탈과 $\mathrm{Br}$ 의 $\mathrm{p}$ 오비탈,
$\mathrm{Pb}$ 의 $\mathrm{p}$ 오비탈간의 혼성화에 의해 페로브스카이트 밴드 내부에 새로운 에너지 준위를 형성했기 때문인 것으로 확인되었다. 이와 유사하게, Ward et al. 연구진은 $\mathrm{Zn}^{2+}$ 와 $\mathrm{Cd}^{2+}$ 를 페로브스카이트의 $\mathrm{B}$ 자리에 양이온 교환법 으로 도핑하는 연구 결과를 보고하였다 (Fig. $4 \mathrm{a}, \mathrm{b}$ ). ${ }^{39)}$ $\mathrm{Zn}^{2+}$ 와 $\mathrm{Cd}^{2+}$ 는 $\mathrm{Pb}^{2+}$ 양이온을 부분적으로 치환하였으 며, 이는 페로브스카이트 나노결정의 흡수 및 방출 파 장의 청색 편이를 유도하였다. 이러한 현상은 $\mathrm{Pb}^{2+}$ 보다 상대적으로 더 작은 이온인 $\mathrm{Zn}^{2+}$ 와 $\mathrm{Cd}^{2+}$ 가 격자 내부 로 도입되면서 $\mathrm{Pb}-\mathrm{X}$ 결합이 더 짧아지게 되고, 이로 인 해 $\mathrm{Pb}$-할로겐화물 octahedra 내에서 더 강한 리간드장 (ligand field)의 형성으로 인한 페로브스카이트 입방 단 위 정(unit cell)의 수축으로부터 기인한 것으로 확인되 었다. 최근에는 3 가 양이온인 $\mathrm{Nd}^{3+}$ 이가(heterovalent) 도핑을 이용하여 청색광을 구현하는 결과도 보고되었다 (Fig. 4c,d) ${ }^{40)} \mathrm{CsPbBr}_{3}$ 에 도핑하는 $\mathrm{Nd}^{3+}$ 의 농도를 증 가시킴에 따라 녹색부터 진청색까지 방출 파장 제어가 가능하였으며, $x=7.2 \%$ 일 때 $\left(\mathrm{CsPBrr}_{3}: \mathrm{xNd}^{3+}\right)$ 방출 (a)

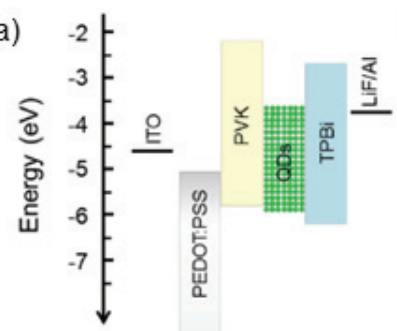

(b)

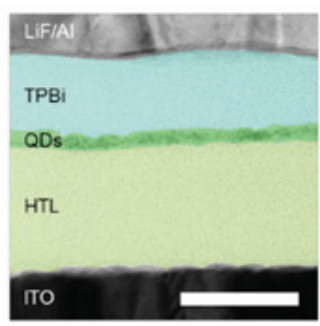

(f)

(e)

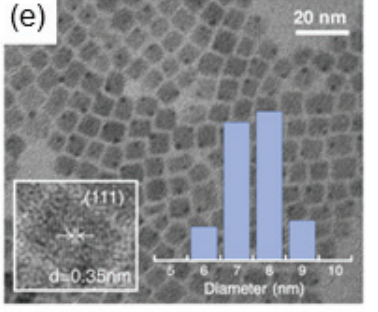

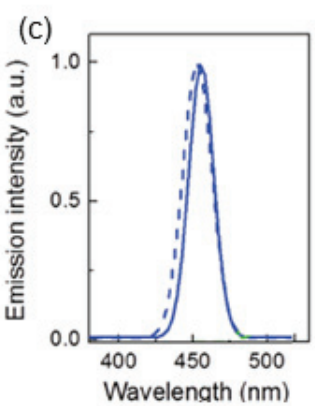

(d)
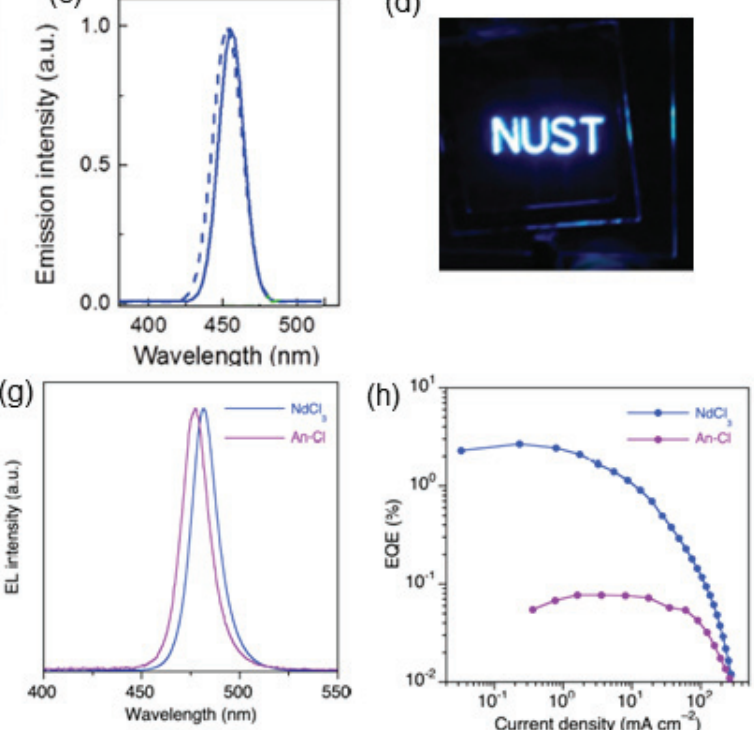

Fig. 5. $\mathrm{CsPbBr}_{3-x} \mathrm{Cl}_{x}$ 나노결정을 이용하여 제작한 청색 LED의 (a) 에너지 밴드 구조, (b) 단면 투과 전자 현미경 이미지(scale bar: 50 $\mathrm{nm})$, (c) EL 스펙트럼 및 (d) 발광 광학 이미지. Reproduced from Song et al. Adv. Mater. 2015;27:7162-7167, with permission of Wiley- $\mathrm{VCH}$ GmbH [41]. (e) $\mathrm{NdCl}_{3}$ 도핑한 $\mathrm{CsPbBr}_{3}$ 나노결정의 투과 전자 현미경 이미지 및 크기 분포. (f) $\mathrm{NdCl}_{3}$ 도핑한 $\mathrm{CsPbBr}_{3}$ 나노결정을 이용하여 제작한 청색 LED의 (f) 에너지 밴드 구조, (g) EL 스펙트럼, (h) 외부 양자 효율. Reproduced from Chiba et al. ACS Appl. Mater. Interfaces. 2020;12:53891-53898, with permission of American Chemical Society [45]. 
파장이 $459 \mathrm{~nm}$ 의 진청 영역임에도 PLQY가 $90 \%$, 반치 전폭이 $19 \mathrm{~nm}$ 로 매우 우수한 광 방출 특성을 보여주었 다. 연구진은 제 1 원리 계산(first principle calculation) 을 통해 $\mathrm{Nd}^{3+}$ 의 B 자리 치환이 병진 대칭(translational symmetry)을 깨뜨려 가전자대 최대점(valence band maximum)을 안정화시키고 전도대 최소점(conduction band minimum)을 불안정하게 만든 결과로 밴드갭 이 변하게 된 것으로 유추하였다. 또한 향상된 PLQY는 $\mathrm{Nd}^{3+}$ 도핑에 따라 가전자대와 전도대의 평탄화로 인한 엑시톤(exciton) 결합 에너지 증가와 더불어 격자의 수 축에 기인한 엑시톤 진동자 강도(oscillator strength)의 향상 때문인 것으로 확인되었다.

\section{4. 폐로브스카이트 니노결정을 이용한 청색 LED}

\section{1. 혼합 할로겐화물 조성의 청색 LED}

페로브스카이트 나노결정을 이용한 최초의 청색 LED 는 2015년 Song et al. 연구진에 의해 보고되었다 (Fig. $5 \mathrm{a}-\mathrm{d}){ }^{41)}$ Hot-injection 방법으로 약 $8 \mathrm{~nm}$ 의 크기를 지니는 입방 형태의 $\mathrm{Br}^{-}$및 $\mathrm{Cl}^{-}$의 혼합 조성으로 이루어 진 $\mathrm{CsPb}\left(\mathrm{Br}_{1-x} \mathrm{Cl}_{x}\right)_{3}(0<\mathrm{x}<1)$ 나노결정을 합성하였으 며, 이를 발광 다이오드에 응용하였다. 이러한 방식으 로 제작된 소자는 전계발광(electroluminescence, EL) 스펙트럼의 파장이 $455 \mathrm{~nm}$, 반치전폭 $20 \mathrm{~nm}, 5.1 \mathrm{~V}$ 의 turn-on 전압 $\left(1 \mathrm{~cd} / \mathrm{m}^{2}\right.$ 에서 $)$ 과 $0.07 \%$ 의 외부 양자 효율, 최대 휘도 $742 \mathrm{~cd} / \mathrm{m}^{2}$ 의 특성을 보여주었다. 고 효율의 청색광 나노결정 기반 $\mathrm{LED}$ 를 구현하기 위해서 는 나노결정 표면에 형성되어 있는 리간드의 밀도는 최 적화하고 표면 결함을 최소화하여 효과적인 전하 주입 을 발생시키는 것이 필요하다. 이를 위해 Pan et al. 연 구진은 합성한 페로브스카이트 나노결정에 oleylamine, oleic acid, di-dodecyl dimethyl ammonium bromide chloride (DDABC)리간드들을 이용한 리간 드 교환법을 통해 표면 엔지니어링을 실시하였다. ${ }^{25)}$ 제 작된 $\mathrm{LED}$ 는 $3.0 \mathrm{~V}$ 의 turn-on 전압, 최대 휘도 $35 \mathrm{~cd} /$ $\mathrm{m}^{2}$, 외부 양자 효율 $1.9 \%$ 를 기록하였다. 상대적으로 낮 은 turn-on 전압은 리간드 밀도 최적화 후 전하 주입율
이 향상되었음을 방증하는 결과이다. 하지만 리간드 교 환 공정은 나노결정의 결정성을 저하시키거나 결정 배 향 변화를 유발하여 나노결정 박막의 균열이나 결함에 의한 소자의 성능 저하를 야기할 수 있다. Li et al. 연구 진은 trimethylaluminum (TMA) 처리를 통한 가교 결 합(cross-linking)법으로 페로브스카이트 나노결정의 긴 알킬 사슬을 짧은 알킬 사슬로 치환하여 이러한 문제 점을 극복하는 방안을 제시하였다. ${ }^{42)}$ 본 방법을 이용하 여 $\mathrm{ITO} / \mathrm{ZnO} / \mathrm{CsPb}\left(\mathrm{Br}_{1-x} \mathrm{Cl}_{x}\right)_{3} / \mathrm{TFB} / \mathrm{MoO}_{3} / \mathrm{Au}$ 의 구조 로 청색 $\mathrm{LED}$ 를 제작하였으며, 제작된 $\mathrm{LED}$ 는 최대 휘도 $8.7 \mathrm{~cd} / \mathrm{m}^{2}$, 외부 양자 효율 $0.0074 \%$ 를 기록하였다.

\subsection{B 자리 도핑을 이용한 청색 LED}

전술하였듯이, 페로브스카이트 나노결정의 도핑을 통해 결정의 결함 준위 밀도를 감소시키고, 결정립계 (grain boundary)를 패시베이션하면 높은 PLQY와 안 정성 및 우수한 전기적 특성을 확보하여 발광 소자의 성 능 향상에도 기여할 수 있다. Hou et al. 연구진은 페로 브스카이트에 미량의 $\mathrm{Mn}$ 을 도핑할 때, 발광 소자의 수 명과 밝기가 크게 향상되는 것을 보고하였다. ${ }^{43)}$ 도핑하 지 않은 소자의 경우, $469 \mathrm{~nm}$ 의 파장에서 최대 휘도 $111 \mathrm{~cd} / \mathrm{m}^{2}$, 외부 양자 효율 $0.50 \%$ 의 성능을 나타내었 지만, 페로브스카이트 나노결정에 $\mathrm{Mn}$ 을 $0.19 \%$ 도핑하 여 $\mathrm{LED}$ 를 제작하였을 때, $466 \mathrm{~nm}$ 의 파장에서 최대 휘 도 $245 \mathrm{~cd} / \mathrm{m}^{2}$, 외부 양자 효율 $2.12 \%$ 로 성능이 크게 향 상되는 것을 관측하였다. 이와 유사하게 Chen et al. 연 구진은 $\mathrm{Cs}_{x} \mathrm{FA}_{1-x} \mathrm{PbBr}_{3}$ 페로브스카이트 나노결정을 합 성하고, $\mathrm{CuCl}_{2}$ 후처리를 통해서 $\mathrm{LED}$ 의 효율을 향상시 키는 결과를 보고하였으며, 제작된 $\mathrm{LED}$ 는 $490 \mathrm{~nm}$ 의 하늘색(sky-blue) 영역에서 최대 휘도 $1946 \mathrm{~cd} / \mathrm{m}^{2}$, 외 부 양자 효율 $5.02 \%$ 의 우수한 성능을 보여주는 것이 확 인되었다. ${ }^{44)}$ 최근에는 $\mathrm{NaCl}_{3}$ 를 도핑하여 발광 소자의 성능을 향상시키는 연구결과도 보고되었다 (Fig. $5 \mathrm{e}^{-}$ h). ${ }^{45)}$ Chiba et al. 연구진은 $\mathrm{CsPbBr}_{3}$ 나노결정을 hotinjection 방법을 이용하여 합성한 후, 상온에서 $\mathrm{NaCl}_{3}$ 후처리를 통해 페로브스카이트 격자 내 도핑을 실시하 였고, 이러한 방식으로 확보된 나노결정은 PLQY가 478 
$\mathrm{nm}$ 에서 $97 \%$ 로 우수한 청색광 발광 특성을 보여주었다. 제작한 $\mathrm{LED}$ 의 성능은 최대 휘도 $138 \mathrm{~cd} / \mathrm{m}^{2}$, 외부 양자 효율 $2.7 \%$ 를 기록하였다.

\section{3. 양자구속효과(quantum confinement effect)를 이용한 bromide 기반 청색 LED}

페로브스카이트에서 할로겐 자리에 $\mathrm{Br}^{-}$및 $\mathrm{Cl}^{-}$를 함 께 사용하는 혼합 조성을 통해 청색 $\mathrm{LED}$ 를 구현하는 것

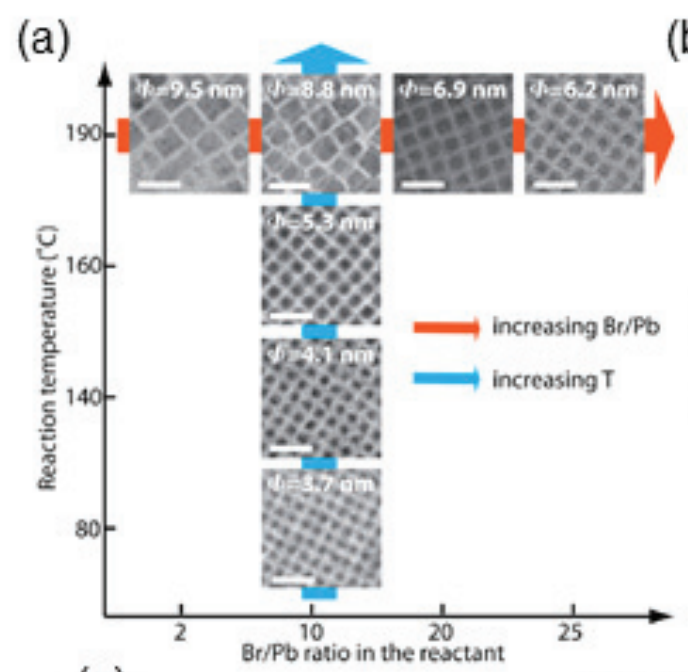

(b)

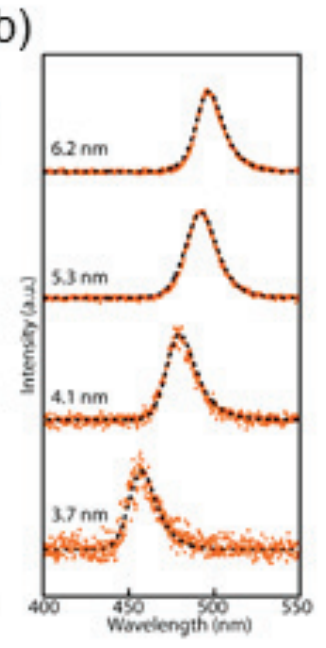

(c)

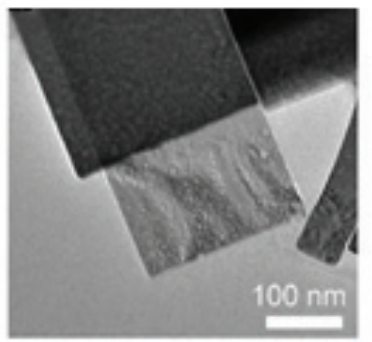

(e)

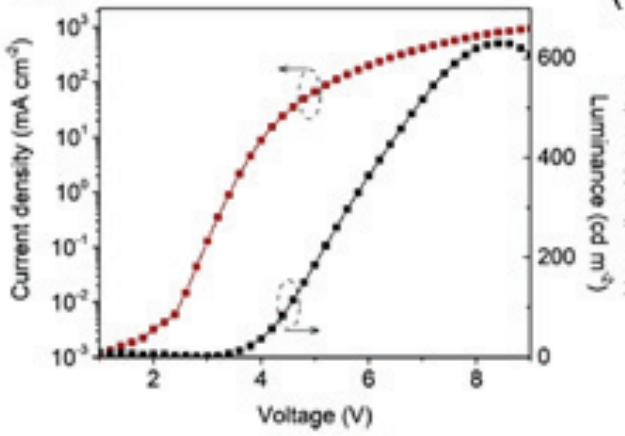

(d)

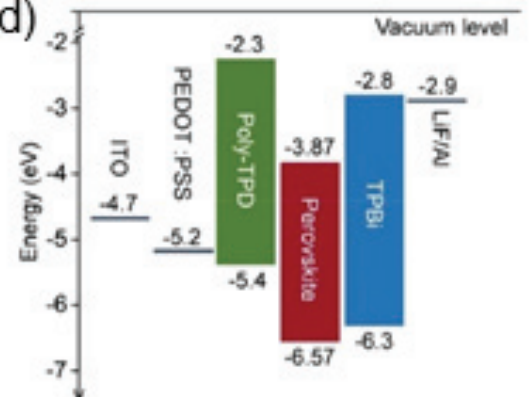

(f) 


\section{특 집 ㄸㅃ 백성두}

이 가장 일반적인 방법이지만, $\mathrm{Cl}^{-}$를 사용하는 경우, 이 로부터 기인하는 페로브스카이트 결정 내 격자 불일치 (lattice mismatch)에 의해 많은 $\mathrm{Cl}^{-}$공공 결함을 형성 하여 재료의 낮은 PLQY를 유발하게 된다. 이와 더불어 소자 구동 시, $\mathrm{Cl}^{-}$이온의 이온 이동(ion migration)에 의한 상분리(phase segregation)를 유발하여 발광 소 자의 낮은 효율, 구동 및 스펙트럼 안정성을 가지고 오 게 된다. ${ }^{46)}$ 이러한 페로브스카이트 재료의 선천적 결함 을 극복하고, 소자의 안정성과 효율성을 향상시키기 위 한 방법으로 $\mathrm{Cl}^{-}$를 사용하지 않고 양자구속효과를 이용 한 $\mathrm{Br}^{-}$기반 청색 $\mathrm{LED}$ 를 구현하는 방법이 보고되었다. 양자구속효과는 나노결정의 반경이 엑시톤 보어(bohr) 반경보다 작아지게 되면 전자와 정공의 운동 방향이 제 한을 받게 되어 재료의 에너지 준위가 불연속적인 값을 가지게 되는 현상이다. 이러한 현상을 이용하면 재료의 크기에 따라 밴드갭을 변화시킬 수 있기에 기존의 II-VI 또는 III-V족 나노결정에서 많이 응용되었다. ${ }^{47)}$ 페로브 스카이트 나노결정에서도 이러한 양자구속효과를 이용 하여 밴드갭을 제어하고 LED에 응용하는 연구가 Dong et al. 연구진에 의해 보고되었다 (Fig. 6a,b). ${ }^{48), 49)}$ 연 구진은 $\mathrm{CsPBrr}_{3}$ 나노결정의 크기를 양자점(quantum dot) 크기로 미세하게 제어하고 균일한 입자들을 확보하 기 위해 기존의 반응속도론적(kinetic) 접근법 대신 열 역학적평형(thermodynamic equilibrium)에 기반한 방 법을 사용하였다. 양자점을 합성할 때, $\mathrm{Br} / \mathrm{Pb}$ 의 비율
과 합성 온도를 제어하여 $\mathrm{CsPbBr}_{3}$ 양자점의 크기를 9.5 $\mathrm{nm}$ 부터 $3.7 \mathrm{~nm}$ 까지 제어할 수 있었으며, 양자구속효 과에 의해 $3.7 \mathrm{~nm}$ 크기를 지니는 양자점은 방출 파장 이 $467 \mathrm{~nm}$ 까지 청색 편이 되는 것이 관측되었다. 이러 한 방법으로 $4 \mathrm{~nm}$ 크기를 지니는 $\mathrm{CsPbBr}_{3}$ 양자점을 합 성하여 청색 $\mathrm{LED}$ 에 적용하였으며, $\mathrm{LED}$ 의 성능을 향상 시키기 위해서 양자점의 표면에 할로겐 음이온 내부 껍 질과 양이온 및 극성 용매 분자의 외부 껍질로 구성되는 양극성(bipolar) 껍질을 형성하는 방법을 도입하였다. 이러한 방식으로 제작된 LED는 약 $480 \mathrm{~nm}$ 의 파장에서 최대 휘도 약 $500 \mathrm{~cd} / \mathrm{m}^{2}$, 외부 양자 효율 $12.3 \%$ 로 매우 우수한 성능을 기록하였다.

0 차원의 양자점 이외에도, 2 차원 형태의 페로브스카 이트 나노플레이트(nanoplatelet) 역시 양자구속효과를 통해 청색 발광 소재로 활용 가능하다. Zhang et al. 연 구진은 최초의 $\mathrm{CsPbBr}_{3}$ 나노플레이트를 합성하고, 이 를 청색 $\mathrm{LED}$ 에 응용하는 결과를 보고하였다. ${ }^{50)}$ 합성 온 도 조절을 통해서 나노플레이트의 두께를 단일층 수준 (monolayer level)으로 미세하게 제어할 수 있었으며, 합성한 나노플레이트를 LED에 응용하였을 때, $480 \mathrm{~nm}$ 의 파장에서 최대 휘도 $25 \mathrm{~cd} / \mathrm{m}^{2}$, 외부 양자 효율이 약 $0.1 \%$ 의 수치를 기록하였다. 상대적으로 다른 페로브스 카이트 청색 $\mathrm{LED}$ 에 비하여 저조한 성능을 보였는데, 이 는 나노플레이트가 넓은 표면적으로 인하여 표면 결함 에 더 취약하고, 두께 감소로 인한 엑시톤의 산란 속도

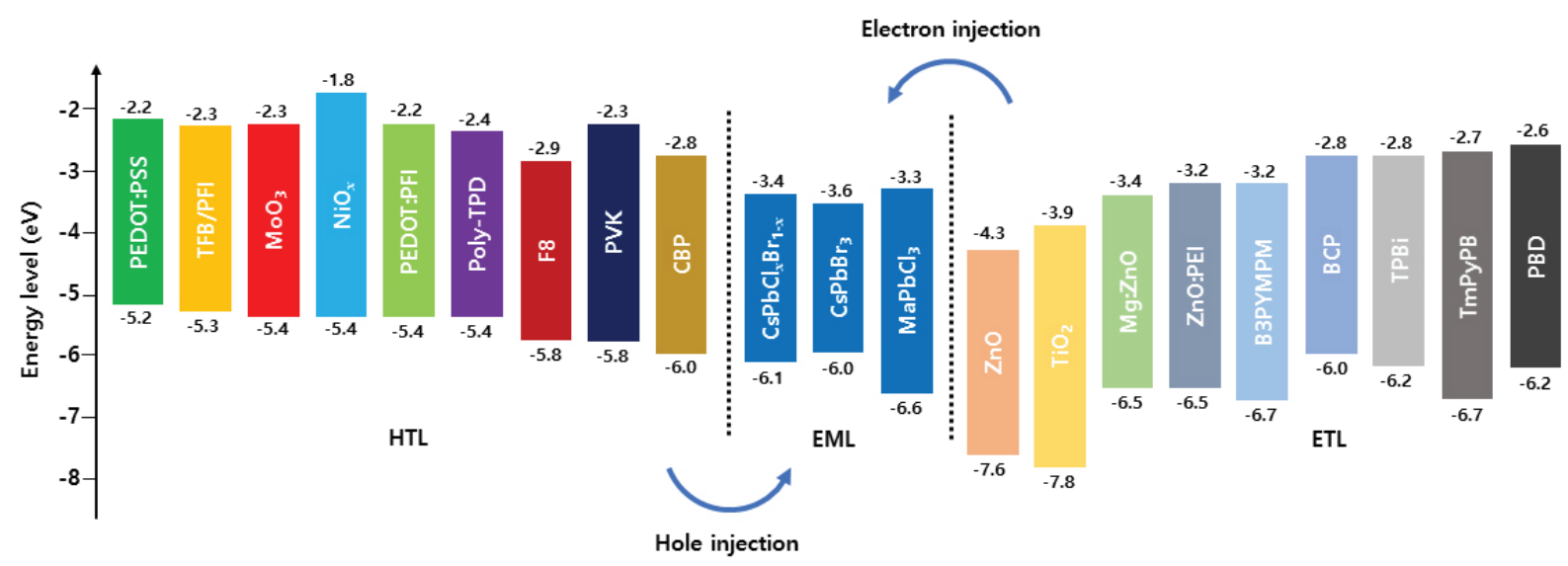

Fig. 7. 다양한 정공 및 전자 수송층과 청색광 페로브스카이트 소재의 에너지 준위. 
증가로 비방사성 재결합율이 증가하였기 때문이다. 이 를 극복하기 위해 $W u$ et al. 연구진은 페로브스카이트 나노플레이트를 $\mathrm{PbBr}_{2}$ 로 패시베이션함으로써 격자 내 부에 존재하는 $\mathrm{Br}$ 공공을 제거하여 PLQY를 약 $96 \%$ 까 지 향상시키는 결과를 보고하였다. ${ }^{51)}$ 또한, 이러한 방 식으로 합성한 $\mathrm{CsPBBr}_{3}$ 나노플레이트를 $\mathrm{LED}$ 에 응용 하였으며, 제작된 $\mathrm{LED}$ 는 파장 $464 \mathrm{~nm}$ 에서 최대 휘도 $62 \mathrm{~cd} / \mathrm{m}^{2}$, 외부 양자 효율 $0.124 \%$ 의 성능을 보여주었 다. 최근에는 여러자리 리간드(multidentate ligand)인 polyethylenimine (PEI)를 템플릿(template)으로 이용 하여 연속적인 조립(assembly)에 의한 우수한 결정성을 지니는 $\mathrm{CsPbrr}_{3}$ 나노플레이트를 합성하고, 이를 $\mathrm{LED}$ 에 응용하는 결과가 보고되었다 (Fig. C-f). ${ }^{52)} \mathrm{PEI}$ 는 효 과적으로 나노플레이트 간의 coalescence를 유도함과 동시에 $\mathrm{Br}^{-}$공공 결함을 억제하여 나노플레이트의 높은 안정성을 확보하는데 기여하였으며, 이를 통해, 방출 파 장 $465 \mathrm{~nm}$ 에서 최대 휘도 $631 \mathrm{~cd} / \mathrm{m}^{2}$, 외부 양자 효율 $0.8 \%$ 의 상대적으로 우수한 특성을 나타내는 발광 소자 가 제작되었다.

\section{4. 청색 $\mathrm{LED}$ 의 소자 구조}

고성능의 페로브스카이트 $\mathrm{LED}$ 를 구현하기 위해서 는 고품위의 페로브스카이트 재료를 확보하는 것이 중 요할 뿐만 아니라 전하를 수송하는 전하 수송층을 최 적화하는 것 또한 필수적이다 (Fig. 7). 청색 페로브스 카이트 $\mathrm{LED}$ 의 효율은 녹색이나 적색 $\mathrm{LED}$ 에 비해 상 당히 낮은데 이러한 차이를 만드는 요인 중 하나는 청 색 $\mathrm{LED}$ 의 낮은 전하 주입율 때문이다. 청색 페로브스 카이트 재료의 밴드갭이 녹색이나 적색 페로브스카이 트 보다 넓기 때문에 이론적인 최소 turn-on 전압 또 한 더 높은 값을 지닌다. 또한 더 넓은 밴드갭으로 인 하여 전도대와 가전자대의 에너지 준위가 녹색이나 적 색에 비해 더 높거나 낮으므로 발광층인 페로브스카이 트로 전하 주입 시, 더 큰 에너지 장벽이 존재하게 된 다. 이러한 에너지 장벽은 전하의 주입을 방해하기 때 문에 발광 소자의 성능 저하를 야기하게 된다. 전하 주 입 문제를 극복하기 위해 발광층과 전하 주입층 간 에
너지 준위 매칭(matching)을 위한 다양한 방법들이 보 고되었다. Gangishetty et al. 연구진은 $[\operatorname{poly}(9,9-$ dioctyl-fluorene-co-N-4-butylphenyl) diphenyl] (TFB) 및 perfluorinated ionomer (PFI) 복합체 층을 $\mathrm{PEDOT}: \mathrm{PSS}$ 층과 발광층 사이에 삽입하여 정공 주입 효율을 향상시키는 연구결과를 보고하였다. ${ }^{53)} \mathrm{TFB}(-$ $5.3 \mathrm{eV})$ 는 PEDOT:PSS(-5.2 eV)보다 더 깊은 highest occupied molecular orbital (HOMO) 준위를 가지고 있기 때문에 정공 주입에 유리할 뿐만 아니라 PFI가 정 공 주입층과 페로브스카이트의 계면에서 강한 표면 쌍 극자 효과에 의한 band bending을 유도하여 정공 주입 을 용이하게 한다. 이러한 에너지 준위 매칭 효과를 바 탕으로 제작된 $\mathrm{LED}$ 는 외부 양자 효율이 기존 $0.03 \%$ 에 서 $0.5 \%$ 까지 크게 향상되는 것으로 확인되었다. $\mathrm{TFB}$ 와 유사한 정공 수송층으로 poly(N-vinylcarbazole) (PVK)가 있으며, PVK는 깊은 $\mathrm{HOMO}$ 준위와 얕은 lowest unoccupied molecular orbital (LUMO) 준위 를 가지고 있기에 정공 수송에 용이할 뿐만 아니라 음 극으로부터 넘어오는 전자를 차단하는 역할도 우수하여 소자의 외부 양자 효율을 크게 개선시킬 수 있다. ${ }^{41)}$

전하 주입 효율을 향상시키는 것 이외에도 전자와 정 공 간 주입 균형 역시 $\mathrm{LED}$ 의 발광 효율과 밀접한 관련 이 있다. 정공 및 전자 수송층의 정공/전자 이동도와 전기적 특성은 전하 주입 균형에 큰 영향을 미치게 되 는데 전하 불균형에 의해 과도한 전자 또는 정공이 수 송층과 페로브스카이트 계면에 축적되게 되면 비방사 성 재결합에 의한 $\mathrm{LED}$ 의 발광 효율 저하를 야기한다 . ${ }^{54)}$ 이러한 현상이 녹색 페로브스카이트 LED에서 발 견되어 보고되었으며, 이를 해결하기 위해 연구진은 polyvinylpyrrolidone (PVP)을 $\mathrm{ZnO}$ 와 페로브스카이 트 층 사이에 삽입하였다. ${ }^{55)}$ 이러한 방식으로 제작된 소 자는 전하 주입 균형이 향상되어 발광 효율이 증진되는 것이 관측되었다. 비슷한 접근법이 청색 $\mathrm{LED}$ 에서도 적 용되었는데, Li et al. 연구진은 정공 주입 속도를 제어 하기 위해 정공 주입층의 두께를 조절하였다. ${ }^{56)}$ 정공 주 입층으로 사용되는 PEDOT:PSS의 두께가 두꺼운 경 우, 정공이 페로브스카이트 층으로 주입되는 시간이 상 
Table 1. 페로브스카이트 나노결정 기반 청색 LED의 성능.

\begin{tabular}{|c|c|c|c|c|}
\hline Device structure & EL $(n m)$ & $L_{\max }\left(c d / m^{2}\right)$ & EQE (\%) & Ref. \\
\hline ITO/PEDOT:PSS/PVK/CsPb $\left(\mathrm{Br}_{1-x} \mathrm{Cl}_{x}\right)_{3} / \mathrm{TPBi} / \mathrm{LiF} / \mathrm{Al}$ & 455 & 742 & 0.07 & 41 \\
\hline ITO/PEDOT:PSS/PVK/CsPb $\left(\mathrm{Br}_{1-x} \mathrm{Cl}_{x}\right)_{3} / \mathrm{TPBi} / \mathrm{LiF} / \mathrm{Al}$ & 490 & 35 & 1.9 & 25 \\
\hline ITO/ZnO/CsPbBr ${ }_{1.5} \mathrm{Cl}_{1.5} / \mathrm{TFB} / \mathrm{MoO}_{3} / \mathrm{Au}$ & 480 & 8.7 & 0.0074 & 42 \\
\hline \multirow{3}{*}{ ITO/PEDOT:PSS/TFB:PFI/CsPb $\left(\mathrm{Br}_{1-x} \mathrm{Cl}_{x}\right)_{3} / \mathrm{TPBi} / \mathrm{LiF} / \mathrm{Al}$} & 469 & 111 & 0.5 & \multirow{3}{*}{53} \\
\hline & 481 & 212 & 0.44 & \\
\hline & 488 & 830 & 1.41 & \\
\hline ITO/PEDOT:PSS/TFB:PFI/Mn ${ }^{2+}$-doped CsPb $\left(\mathrm{Br}_{1-x} \mathrm{Cl}_{x}\right)_{3} / \mathrm{TPBi} / \mathrm{LiF} / \mathrm{Al}$ & 466 & 245 & 2.12 & 43 \\
\hline ITO/PEDOT:PSS/PVK/CH ${ }_{3} \mathrm{NH}_{3} \mathrm{~Pb}\left(\mathrm{Br}_{1-x} \mathrm{Cl}_{x}\right)_{3} / \mathrm{TPBi} / \mathrm{LiF} / \mathrm{Al}$ & 445 & 2673 & 1.38 & 57 \\
\hline ITO/PEDOT:PSS/TFB/CsPb $\left(\mathrm{Br}_{1-x}\left(\mathrm{Cl}_{x}\right)_{3} / \mathrm{TPBi} / \mathrm{Liq} / \mathrm{Al}\right.$ & 456 & 43.2 & 1.1 & 58 \\
\hline $\mathrm{ITO} / \mathrm{NiO}_{x} / \mathrm{CsPb}\left(\mathrm{Br}_{1-x} \mathrm{Cl}_{x}\right)_{3} / \mathrm{TPBi} / \mathrm{LiF} / \mathrm{Al}$ & 470 & 350 & 0.07 & 59 \\
\hline ITO/PEDOT:PSS/Poly-TPD/PVK/Cs ${ }_{x} \mathrm{MA}_{1-x} \mathrm{PbBr}_{3} / \mathrm{TmPyPB} \mathrm{LiF} / \mathrm{Al}$ & 465 & $\sim 60$ & 2.4 & 60 \\
\hline ITO/PEDOT:PSS/PTAA/CsPbBr ${ }_{3} / \mathrm{TPBi} / \mathrm{LiF} / \mathrm{Al}$ & $<480$ & $\sim 500$ & 12.3 & 49 \\
\hline ITO/PEDOT:PSS/Poly-TPD/PVK/K $\mathrm{K}^{+}$-passivated $\mathrm{CsPb}\left(\mathrm{Br}_{1-x} \mathrm{Cl}_{x}\right)_{3} / \mathrm{PO}-\mathrm{T} 2 \mathrm{~T} / \mathrm{LiF} / \mathrm{Al}$ & 477 & 86.95 & 1.96 & 61 \\
\hline ITO/PEDOT:PSS/Poly-TPD/Ni2+-doped CsPb $\left(\mathrm{Br}_{1.7} \mathrm{Cl}_{1.3}\right)_{3} / \mathrm{TPBi} / \mathrm{LiF} / \mathrm{Al}$ & 460 & 33 & 1.35 & 62 \\
\hline \multirow{2}{*}{ ITO/PEDOT:PSS/Poly-TPD/Rb ${ }_{x} \mathrm{Cs}_{1-x} \mathrm{PbBr}_{3} / \mathrm{TPBi} / \mathrm{LiF} / \mathrm{Al}$} & 464 & 71 & 0.11 & \multirow{2}{*}{63} \\
\hline & 490 & 186 & 0.87 & \\
\hline ITO/PEDOT:PSS/Poly-TPD/CBP/CsPb(Br$\left.\left.{ }_{1-x} \mathrm{Cl}\right|_{x}\right)_{3} / \mathrm{B} 3 \mathrm{PYMPM} / \mathrm{LiF} / \mathrm{Al}$ & 463 & 318 & 1.4 & 64 \\
\hline ITO/PEDOT:PSS/PTAA/CuCl - -treated $\mathrm{Cs}_{x} \mathrm{FA}_{1-x} \mathrm{PbBr}_{3} / \mathrm{TOPO} / \mathrm{TPBi} / \mathrm{LiF} / \mathrm{Al}$ & 490 & 1946 & 5.02 & 44 \\
\hline ITO/PEDOT:PSS/TFB/NdCl ${ }_{3}$-doped CsPb $\left(\mathrm{Br}_{1-x} \mathrm{Cl}_{x}\right)_{3} / \mathrm{TPBi} / \mathrm{Liq} / \mathrm{Al}$ & 478 & 138 & 2.7 & 45 \\
\hline
\end{tabular}

대적으로 오래 걸리게 되며, 두께가 너무 얇은 경우에 는 하부 전극과의 직접적인 접촉이 일어나는 부분이 존 재하여 심각한 누설 전류가 발생하는 것이 확인되었다. $\mathrm{PEDOT}: \mathrm{PSS}$ 두께가 $15 \mathrm{~nm}$ 로 최적화되었을 때, 정공 과 전자의 주입 시간이 거의 같아지는 것이 관측되었으 며, 결과적으로 소자의 발광성 재결합 중심(radiative recombination center)이 계면이 아닌 페로브스카이트 에 위치하게 되어 $5.7 \%$ 의 높은 외부 양자 효율을 기록 하는 것이 관측되었다. 페로브스카이트 나노결정을 이 용한 청색 $\mathrm{LED}$ 의 최근까지의 연구 결과를 Table 1에 요 약하였다.

\section{5. 결론}

본 총설에서는 페로브스카이트 나노결정의 합성법과 조성 제어, 그리고 청색 $\mathrm{LED}$ 로의 응용에 관한 연구동향 을 살펴보았다. 고성능의 페로브스카이트 청색 $\mathrm{LED}$ 구 현을 위해서는 고품위의 페로브스카이트 나노결정을 확 보하는 것이 선행되어야 하며, 이를 위해 나노결정 표면 의 유기 리간드 제어 및 도핑/치환을 이용한 결함 억제 를 실시하는 것이 효과적이다. 현재까지 이러한 연구가 광범위하게 이루어졌으나, 나노결정 자체 특성 향상에 대한 보고가 주를 이루며, 이를 직접적으로 $\mathrm{LED}$ 에 적 
용하여 LED 성능 향상을 유도한 연구 결과는 아직까지 많이 부족한 실정이므로 이에 대한 더 많은 연구가 필요 하다. 청색 방출 파장의 구현 측면에서는 기존의 혼합 $\mathrm{Br}^{-} / \mathrm{Cl}^{-}$조성 기반의 청색 $\mathrm{LED}$ 가 $\mathrm{Cl}^{-}$공공 결함과 이 온 이동에 의해 낮은 광효율 및 안정성을 보이게 되므로 $\mathrm{Br}^{-}$만을 이용하되, 페로브스카이트의 B 자리 도핑/치환 법이나 결정의 크기 및 차원 제어를 통해 양자구속효과 에 기인한 청색광 구현법으로 접근하는 것이 성능 개선 측면에서 더 효과적일 것으로 판단된다. 발광층의 개선 과 더불어, 전하 주입/수송층의 최적화 역시 중요하다. 전하 주입에 용이한 적절한 에너지 밴드 정렬을 가지는 재료들을 선정하여 계면에서 발생하는 비방사성 재결합 율을 감소시키고, 전하 주입 균형을 맞추어 주는 것이 발광 소자의 성능 향상을 위해 필수적이다. 비록 고성능 의 청색광 페로브스카이트 LED 구현을 위해서 여전히 해결해야 할 많은 문제들이 산적해 있지만, 페로브스카 이트 $\mathrm{LED}$ 는 상대적으로 짧은 연구 개발 역사에도 불구 하고 높은 수준의 결과물들이 보고되고 있다. 따라서 지 속적이며 심도 있는 연구를 통해 머지않은 미래에 조명 및 디스플레이 분야에서 핵심 소재로 발돋움할 수 있을 것으로 기대해 본다.

\section{ACKNOWLEDGMENT}

이 논문은 2021년도 정부(과기정통부)의 재원으로 한 국연구재단 혁신성장선도고급연구인재육성(KIURI) 시범사업의 지원을 받아 수행된 연구임(No. NRF2020M3H1A1077207).

\section{REFERENCES}

1. Y. Li, X. Zhang, H. Huang, S. V. Kershaw, A.L. Rogach, "Advances in metal halide perovskite nanocrystals: Synthetic strategies, growth mechanisms, and optoelectronic applications." Mater. Today. 32: 204-221 (2020).

2. M. V. Kovalenko, L. Protesescu, M.I. Bodnarchuk, "Properties and potential optoelectronic applications of lead halide perovskite nanocrystals." Science.
358(6364): 745-750 (2017).

3. H. Huang, L. Polavarapu, J.A. Sichert, A.S. Susha, A.S. Urban, A.L. Rogach, Colloidal lead halide perovskite nanocrystals: synthesis, optical properties and applications, NPG Asia Mater. 8(11): e328 (2016)

4. M. M. Lee, J. Teuscher, T. Miyasaka, T. N. Murakami, H. J. Snaith, "Efficient Hybrid Solar Cells Based on Meso-Superstructured Organometal Halide Perovskites." Science. 338(6107): 643-647 (2012).

5. G. Xing, N. Mathews, S.S. Lim, N. Yantara, X. Liu, D. Sabba, M. Grätzel, S. Mhaisalkar, T.C. Sum, "Lowtemperature solution-processed wavelength-tunable perovskites for lasing." Nat. Mater. 13(5): 476-480 (2014).

6. J. Jeong, M. Kim, J. Seo, H. Lu, P. Ahlawat, A. Mishra, Y. Yang, M.A. Hope, F.T. Eickemeyer, M. Kim, Y.J. Yoon, I.W. Choi, B.P. Darwich, S.J. Choi, Y. Jo, J.H. Lee, B. Walker, S.M. Zakeeruddin, L. Emsley, U. Rothlisberger, A. Hagfeldt, D.S. Kim, M. Grätzel, J.Y. Kim, "Pseudo-halide anion engineering for $\alpha-\mathrm{FAPbI}_{3}$ perovskite solar cells." Nature. 592(7854): 381-385 (2021).

7. Z.-K. Tan, R.S. Moghaddam, M.L. Lai, P. Docampo, R. Higler, F. Deschler, M. Price, A. Sadhanala, L.M. Pazos, D. Credgington, F. Hanusch, T. Bein, H.J. Snaith, R.H. Friend, "Bright light-emitting diodes based on organometal halide perovskite." Nat. Nanotechnol. 9(9): 687-692 (2014).

8. Y. Cao, N. Wang, H. Tian, J. Guo, Y. Wei, H. Chen, Y. Miao, W. Zou, K. Pan, Y. He, H. Cao, Y. Ke, M. Xu, Y. Wang, M. Yang, K. Du, Z. Fu, D. Kong, D. Dai, Y. Jin, G. Li, H. Li, Q. Peng, J. Wang, W. Huang, "Perovskite light-emitting diodes based on spontaneously formed submicrometre-scale structures." Nature. 562(7726): 249-253 (2018).

9. K. Lin, J. Xing, L.N. Quan, F.P.G. de Arquer, X. Gong, J. Lu, L. Xie, W. Zhao, D. Zhang, C. Yan, W. Li, X. Liu, Y. Lu, J. Kirman, E.H. Sargent, Q. Xiong, Z. Wei, "Perovskite light-emitting diodes with external quantum efficiency exceeding 20 per cent." Nature. 562(7726): 245-248 (2018).

10. T. Chiba, Y. Hayashi, H. Ebe, K. Hoshi, J. Sato, S. Sato, Y.J. Pu, S. Ohisa, J. Kido, “Anion-exchange red perovskite quantum dots with ammonium iodine salts for highly efficient light-emitting devices." Nat. Photonics. 12(11): 681-687 (2018). 
11. X.-B. Shi, Y. Liu, Z. Yuan, X.-K. Liu, Y. Miao, J. Wang, S. Lenk, S. Reineke, F. Gao, "Optical Energy Losses in Organic-Inorganic Hybrid Perovskite LightEmitting Diodes." Adv. Opt. Mater. 6(17): 1800667 (2018).

12. M. Luo, Y. Jiang, T. He, M. Yuan, "Metal halide perovskites for blue light emitting materials." APL Mater. 8(4): 040907 (2020).

13. C.B. Murray, C.R. Kagan, M.G. Bawendi, "Synthesis and Characterization of Monodisperse Nanocrystals and Close-Packed Nanocrystal Assemblies." Annu. Rev. Mater. Sci. 30(1): 545-610 (2000).

14. L. Protesescu, S. Yakunin, M. I. Bodnarchuk, F. Krieg, R. Caputo, C. H. Hendon, R.X. Yang, A. Walsh, M. V. Kovalenko, "Nanocrystals of Cesium Lead Halide Perovskites $\left(\mathrm{CsPbX}_{3}, \mathrm{X}=\mathrm{Cl}, \mathrm{Br}\right.$, and I): Novel Optoelectronic Materials Showing Bright Emission with Wide Color Gamut." Nano Lett. 15(6): 36923696 (2015).

15. O. Vybornyi, S. Yakunin, M. V. Kovalenko, "Polarsolvent-free colloidal synthesis of highly luminescent alkylammonium lead halide perovskite nanocrystals." Nanoscale. 8(12): 6278-6283 (2016).

16. L. Protesescu, S. Yakunin, S. Kumar, J. Bär, F. Bertolotti, N. Masciocchi, A. Guagliardi, M. Grotevent, I. Shorubalko, M.I. Bodnarchuk, C.-J. Shih, M. V. Kovalenko, "Dismantling the "Red Wall" of Colloidal Perovskites: Highly Luminescent Formamidinium and Formamidinium-Cesium Lead Iodide Nanocrystals.” ACS Nano. 11(3): 3119-3134 (2017).

17. F. Zhang, H. Zhong, C. Chen, X. Wu, X. Hu, H. Huang, J. Han, B. Zou, Y. Dong, "Brightly Luminescent and Color-Tunable Colloidal $\mathrm{CH}_{3} \mathrm{NH}_{3} \mathrm{PbX}_{3}(\mathrm{X}=\mathrm{Br}, \mathrm{I}, \mathrm{Cl})$ Quantum Dots: Potential Alternatives for Display Technology." ACS Nano. 9(4): 4533-4542 (2015).

18. G.C. Papavassiliou, G. Pagona, N. Karousis, G.A. Mousdis, I. Koutselas, A. Vassilakopoulou, "Nanocrystalline/microcrystalline materials based on lead-halide units." J. Mater. Chem. 22(17): 8271 (2012).

19. J. Shamsi, A.S. Urban, M. Imran, L. De Trizio, L. Manna, "Metal Halide Perovskite Nanocrystals: Synthesis, Post-Synthesis Modifications, and Their Optical Properties." Chem. Rev. 119(5): 3296-3348 (2019).
20. S. Sun, D. Yuan, Y. Xu, A. Wang, Z. Deng, "LigandMediated Synthesis of Shape-Controlled Cesium Lead Halide Perovskite Nanocrystals via Reprecipitation Process at Room Temperature." ACS Nano. 10(3): 3648-3657 (2016).

21. E. Yassitepe, Z. Yang, O. Voznyy, Y. Kim, G. Walters, J. A. Castañeda, P. Kanjanaboos, M. Yuan, X. Gong, F. Fan, J. Pan, S. Hoogland, R. Comin, O.M. Bakr, L.A. Padilha, A.F. Nogueira, E.H. Sargent, "AmineFree Synthesis of Cesium Lead Halide Perovskite Quantum Dots for Efficient Light-Emitting Diodes.” Adv. Funct. Mater. 26(47): 8757-8763 (2016).

22. H. Huang, B. Chen, Z. Wang, T.F. Hung, A.S. Susha, H. Zhong, A.L. Rogach, "Water resistant $\mathrm{CsPbX}_{3}$ nanocrystals coated with polyhedral oligomeric silsesquioxane and their use as solid state luminophores in all-perovskite white light-emitting devices." Chem. Sci. 7(9): 5699-5703 (2016).

23. B. Luo, Y.-C. Pu, S.A. Lindley, Y. Yang, L. Lu, Y. Li, X. Li, J.Z. Zhang, "Organolead Halide Perovskite Nanocrystals: Branched Capping Ligands Control Crystal Size and Stability." Angew. Chemie Int. Ed. 55(31): 8864-8868 (2016).

24. L. Wu, Q. Zhong, D. Yang, M. Chen, H. Hu, Q. Pan, H. Liu, M. Cao, Y. Xu, B. Sun, Q. Zhang, "Improving the Stability and Size Tunability of Cesium Lead Halide Perovskite Nanocrystals Using Trioctylphosphine Oxide as the Capping Ligand." Langmuir. 33(44): 12689-12696 (2017).

25. J. Pan, L.N. Quan, Y. Zhao, W. Peng, B. Murali, S.P. Sarmah, M. Yuan, L. Sinatra, N.M. Alyami, J. Liu, E. Yassitepe, Z. Yang, O. Voznyy, R. Comin, M.N. Hedhili, O.F. Mohammed, Z.H. Lu, D.H. Kim, E.H. Sargent, O.M. Bakr, "Highly Efficient PerovskiteQuantum-Dot Light-Emitting Diodes by Surface Engineering." Adv. Mater. 28(39): 8718-8725 (2016).

26. J. Woo Choi, H.C. Woo, X. Huang, W.-G. Jung, B.-J. Kim, S.-W. Jeon, S.-Y. Yim, J.-S. Lee, C.-L. Lee, "Organic-inorganic hybrid perovskite quantum dots with high PLQY and enhanced carrier mobility through crystallinity control by solvent engineering and solid-state ligand exchange." Nanoscale. 10(28): 13356-13367 (2018).

27. G. Nedelcu, L. Protesescu, S. Yakunin, M.I. Bodnarchuk, M.J. Grotevent, M. V. Kovalenko, "Fast Anion-Exchange in Highly Luminescent Nanocrystals of Cesium Lead Halide Perovskites $\left(\mathrm{CsPbX}_{3}, \mathrm{X}=\mathrm{Cl}\right.$, 
Br, I).” Nano Lett. 15(8): 5635-5640 (2015).

28. X. Zheng, C. Wu, S.K. Jha, Z. Li, K. Zhu, S. Priya, "Improved Phase Stability of Formamidinium Lead Triiodide Perovskite by Strain Relaxation." ACS Energy Lett. 1(5): 1014-1020 (2016).

29. A. Swarnkar, V.K. Ravi, A. Nag, Beyond Colloidal Cesium Lead Halide Perovskite Nanocrystals: Analogous Metal Halides and Doping, ACS Energy Lett. 2(5): 1089-1098 (2017).

30. C.-H. Lu, G. V. Biesold-McGee, Y. Liu, Z. Kang, Z. Lin, "Doping and ion substitution in colloidal metal halide perovskite nanocrystals." Chem. Soc. Rev. 49(14): 4953-5007 (2020).

31. S. Zou, Y. Liu, J. Li, C. Liu, R. Feng, F. Jiang, Y. Li, J. Song, H. Zeng, M. Hong, X. Chen, "Stabilizing Cesium Lead Halide Perovskite Lattice through Mn(II) Substitution for Air-Stable Light-Emitting Diodes." J. Am. Chem. Soc. 139(33): 11443-11450 (2017).

32. C. Bi, S. Wang, Q. Li, S. V. Kershaw, J. Tian, A. L. Rogach, "Thermally Stable Copper(II)-Doped Cesium Lead Halide Perovskite Quantum Dots with Strong Blue Emission.” J. Phys. Chem. Lett. 10(5): 943-952 (2019).

33. D. Parobek, B. J. Roman, Y. Dong, H. Jin, E. Lee, M. Sheldon, D.H. Son, "Exciton-to-Dopant Energy Transfer in Mn-Doped Cesium Lead Halide Perovskite Nanocrystals." Nano Lett. 16(12): 73767380 (2016).

34. H. Liu, Z. Wu, J. Shao, D. Yao, H. Gao, Y. Liu, W. $\mathrm{Yu}, \mathrm{H}$. Zhang, B. Yang, "CsPb $\mathrm{Mn}_{1-\mathrm{x}} \mathrm{Cl}_{3}$ Perovskite Quantum Dots with High Mn Substitution Ratio." ACS Nano. 11(2): 2239-2247 (2017).

35. Z.-J. Yong, S.-Q. Guo, J.-P. Ma, J.-Y. Zhang, Z.-Y. Li, Y.-M. Chen, B.-B. Zhang, Y. Zhou, J. Shu, J.-L. Gu, L.-R. Zheng, O. M. Bakr, H.-T. Sun, "DopingEnhanced Short-Range Order of Perovskite Nanocrystals for Near-Unity Violet Luminescence Quantum Yield.” J. Am. Chem. Soc. 140(31): 99429951 (2018).

36. G. H. Ahmed, J. K. El-Demellawi, J. Yin, J. Pan, D. B. Velusamy, M. N. Hedhili, E. Alarousu, O. M. Bakr, H. N. Alshareef, O. F. Mohammed, "Giant Photoluminescence Enhancement in $\mathrm{CsPbCl}_{3}$ Perovskite Nanocrystals by Simultaneous DualSurface Passivation.” ACS Energy Lett. 3(10): 2301-
2307 (2018).

37. Q. A. Akkerman, V. D'Innocenzo, S. Accornero, A. Scarpellini, A. Petrozza, M. Prato, L. Manna, "Tuning the Optical Properties of Cesium Lead Halide Perovskite Nanocrystals by Anion Exchange Reactions." J. Am. Chem. Soc. 137(32): 10276-10281 (2015).

38. M. Liu, G. Zhong, Y. Yin, J. Miao, K. Li, C. Wang, X. Xu, C. Shen, H. Meng, "Aluminum-Doped Cesium Lead Bromide Perovskite Nanocrystals with Stable Blue Photoluminescence Used for Display Backlight.” Adv. Sci. 4(11): 1700335 (2017).

39. W. van der Stam, J. J. Geuchies, T. Altantzis, K. H. W. van den Bos, J. D. Meeldijk, S. Van Aert, S. Bals, D. Vanmaekelbergh, C. de Mello Donega, "Highly Emissive Divalent-Ion-Doped Colloidal $\mathrm{CsPb}_{1-\mathrm{x}} \mathrm{M}_{\mathrm{x}} \mathrm{Br}_{3}$ Perovskite Nanocrystals through Cation Exchange." J. Am. Chem. Soc. 139(11): 4087-4097 (2017).

40. Y. Xie, B. Peng, I. Bravić, Y. Yu, Y. Dong, R. Liang, Q. Ou, B. Monserrat, S. Zhang, "Highly Efficient Blue-Emitting $\mathrm{CsPbBr}_{3}$ Perovskite Nanocrystals through Neodymium Doping." Adv. Sci. 7(20): 2001698 (2020).

41. J. Song, J. Li, X. Li, L. Xu, Y. Dong, H. Zeng, "Quantum Dot Light-Emitting Diodes Based on Inorganic Perovskite Cesium Lead Halides (CsPbX ${ }_{3}$ ).” Adv. Mater. 27(44): $7162-7167$ (2015).

42. G. Li, F.W.R. Rivarola, N.J.L.K. Davis, S. Bai, T. C. Jellicoe, F. de la Peña, S. Hou, C. Ducati, F. Gao, R. H. Friend, N.C. Greenham, Z.-K. Tan, "Highly Efficient Perovskite Nanocrystal Light-Emitting Diodes Enabled by a Universal Crosslinking Method." Adv. Mater. 28(18): 3528-3534 (2016).

43. S. Hou, M. K. Gangishetty, Q. Quan, D. N. Congreve, "Efficient Blue and White Perovskite Light-Emitting Diodes via Manganese Doping.” Joule. 2(11): 24212433 (2018).

44. F. Chen, L. Xu, Y. Li, T. Fang, T. Wang, M. Salerno, M. Prato, J. Song, "Highly efficient sky-blue lightemitting diodes based on Cu-treated halide perovskite nanocrystals.” J. Mater. Chem. C. 8(38): 13445-13452 (2020).

45. T. Chiba, J. Sato, S. Ishikawa, Y. Takahashi, H. Ebe, S. Sumikoshi, S. Ohisa, J. Kido, "Neodymium Chloride-Doped Perovskite Nanocrystals for Efficient Blue Light-Emitting Devices.” ACS Appl. Mater. 
Interfaces. 12(48): 53891-53898 (2020).

46. C.-H.A. Li, Z. Zhou, P. Vashishtha, J.E. Halpert, "The Future Is Blue (LEDs): Why Chemistry Is the Key to Perovskite Displays." Chem. Mater. 31(16): 60036032 (2019).

47. S. Baskoutas, A.F. Terzis, "Size-dependent band gap of colloidal quantum dots." J. Appl. Phys. 99(1): 013708 (2006).

48. Y. Dong, T. Qiao, D. Kim, D. Parobek, D. Rossi, D.H. Son, "Precise Control of Quantum Confinement in Cesium Lead Halide Perovskite Quantum Dots via Thermodynamic Equilibrium." Nano Lett. 18(6): 3716-3722 (2018).

49. Y. Dong, Y.-K. Wang, F. Yuan, A. Johnston, Y. Liu, D. Ma, M.-J. Choi, B. Chen, M. Chekini, S.-W. Baek, L.K. Sagar, J. Fan, Y. Hou, M. Wu, S. Lee, B. Sun, S. Hoogland, R. Quintero-Bermudez, H. Ebe, P. Todorovic, F. Dinic, P. Li, H.T. Kung, M.I. Saidaminov, E. Kumacheva, E. Spiecker, L.-S. Liao, O. Voznyy, Z.-H. Lu, E.H. Sargent, "Bipolar-shell resurfacing for blue LEDs based on strongly confined perovskite quantum dots." Nat. Nanotechnol. 15(8): 668-674 (2020).

50. D. Yang, Y. Zou, P. Li, Q. Liu, L. Wu, H. Hu, Y. $\mathrm{Xu}, \mathrm{B}$. Sun, Q. Zhang, S.-T. Lee, "Large-scale synthesis of ultrathin cesium lead bromide perovskite nanoplates with precisely tunable dimensions and their application in blue light-emitting diodes." Nano Energy. 47: 235-242 (2018).

51. Y. Wu, C. Wei, X. Li, Y. Li, S. Qiu, W. Shen, B. Cai, Z. Sun, D. Yang, Z. Deng, H. Zeng, "In Situ Passivation of $\mathrm{PbBr}_{6}{ }^{4-}$ Octahedra toward Blue Luminescent $\mathrm{CsPbBr}_{3}$ Nanoplatelets with Near 100\% Absolute Quantum Yield." ACS Energy Lett. 3(9): 2030-2037 (2018).

52. W. Yin, M. Li, W. Dong, Z. Luo, Y. Li, J. Qian, J. Zhang, W. Zhang, Y. Zhang, S. V. Kershaw, X. Zhang, W. Zheng, A.L. Rogach, "Multidentate Ligand Polyethylenimine Enables Bright Color-Saturated Blue Light-Emitting Diodes Based on $\mathrm{CsPbBr}_{3}$ Nanoplatelets." ACS Energy Lett. 6(2): 477-484 (2021).

53. M. K. Gangishetty, S. Hou, Q. Quan, D. N. Congreve, "Reducing Architecture Limitations for Efficient Blue Perovskite Light-Emitting Diodes." Adv. Mater. 30(20): 1706226 (2018).
54. W. Zou, R. Li, S. Zhang, Y. Liu, N. Wang, Y. Cao, Y. Miao, M. Xu, Q. Guo, D. Di, L. Zhang, C. Yi, F. Gao, R.H. Friend, J. Wang, W. Huang, "Minimising efficiency roll-off in high-brightness perovskite lightemitting diodes." Nat. Commun. 9(1): 608 (2018).

55. L. Zhang, X. Yang, Q. Jiang, P. Wang, Z. Yin, X. Zhang, H. Tan, Y. Yang, M. Wei, B.R. Sutherland, E.H. Sargent, J. You, "Ultra-bright and highly efficient inorganic based perovskite light-emitting diodes." Nat. Commun. 8(): 15640 (2017).

56. Z. Li, Z. Chen, Y. Yang, Q. Xue, H.-L. Yip, Y. Cao, "Modulation of recombination zone position for quasi-two-dimensional blue perovskite light-emitting diodes with efficiency exceeding 5\%." Nat. Commun. 10(1): 1027 (2019).

57. W. Deng, X. Xu, X. Zhang, Y. Zhang, X. Jin, L. Wang, S.-T. Lee, J. Jie, "Organometal Halide Perovskite Quantum Dot Light-Emitting Diodes.” Adv. Funct. Mater. 26(26): 4797-4802 (2016).

58. T. Chiba, S. Ishikawa, J. Sato, Y. Takahashi, H. Ebe, S. Ohisa, J. Kido, "Blue Perovskite Nanocrystal Light-Emitting Devices via the Ligand Exchange with Adamantane Diamine." Adv. Opt. Mater. 8(13): 2000289 (2020).

59. E.-P. Yao, Z. Yang, L. Meng, P. Sun, S. Dong, Y. Yang, Y. Yang, "High-Brightness Blue and White LEDs based on Inorganic Perovskite Nanocrystals and their Composites.” Adv. Mater. 29(23): 1606859 (2017).

60. W. Xu, R. Ji, P. Liu, L. Cheng, L. Zhu, J. Zhang, H. Chen, Y. Tong, C. Zhang, Z. Kuang, H. Zhang, J. Lai, K. Wen, P. Yang, N. Wang, W. Huang, J. Wang, "In Situ-Fabricated Perovskite Nanocrystals for DeepBlue Light-Emitting Diodes.” J. Phys. Chem. Lett. 11(24): 10348-10353 (2020).

61. F. Yang, H. Chen, R. Zhang, X. Liu, W. Zhang, J. Zhang, F. Gao, L. Wang, "Efficient and Spectrally Stable Blue Perovskite Light-Emitting Diodes Based on Potassium Passivated Nanocrystals." Adv. Funct. Mater. 30(10): 1908760 (2020).

62. B.-B. Zhang, S. Yuan, J.-P. Ma, Y. Zhou, J. Hou, X. Chen, W. Zheng, H. Shen, X.-C. Wang, B. Sun, O.M. Bakr, L.-S. Liao, H.-T. Sun, “General Mild Reaction Creates Highly Luminescent Organic-Ligand-Lacking Halide Perovskite Nanocrystals for Efficient LightEmitting Diodes.” J. Am. Chem. Soc. 141(38): 15423 15432 (2019). 
63. P. Todorović, D. Ma, B. Chen, R. Quintero-Bermudez, M. I. Saidaminov, Y. Dong, Z. Lu, E. H. Sargent, "Spectrally Tunable and Stable Electroluminescence Enabled by Rubidium Doping of $\mathrm{CsPBBr}_{3}$ Nanocrystals." Adv. Opt. Mater. 7(24): 1901440 (2019).
64. S. T. Ochsenbein, F. Krieg, Y. Shynkarenko, G. Rainò, M. V. Kovalenko, "Engineering Color-Stable Blue Light-Emitting Diodes with Lead Halide Perovskite Nanocrystals." ACS Appl. Mater. Interfaces. 11(24): 21655-21660 (2019).

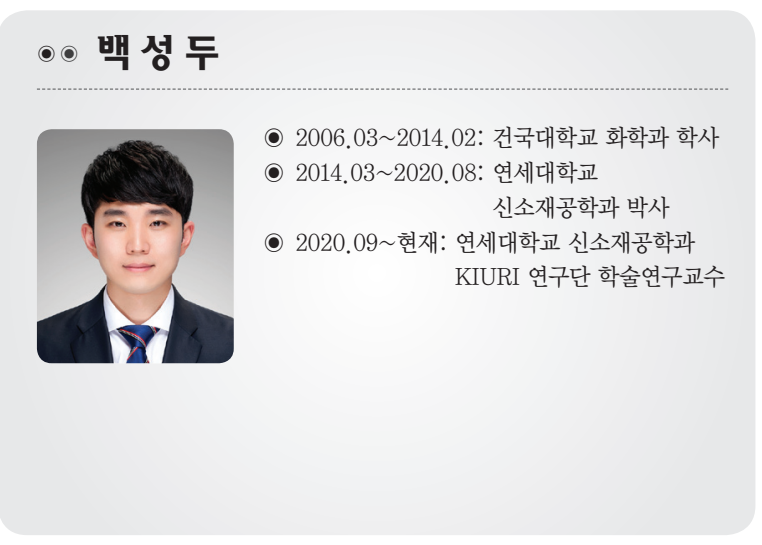

